\title{
Psihiatriskās aprūpes problēmas Latvijā 20. gs. 20.-30. gados
}

Medicīniskā izpratnē psihiatrijai ir visai nesena vēsture, kaut gan garīgās slimības cilvēcei paz̄̄stamas jau kopš senajiem laikiem, un vienmēr ir bijuši cilvēki, kuru pienākums vai iniciatīva bija rūpes par slimajiem. Par psihiatrijas kā medicīnas nozares sākumu pieņemts uzskatīt 18. gs. beigas, kad sākumā Francijā, vēlāk arī pārējā Rietumu pasaulē sākās pārmaiņas psihiatriskajā aprūpē un tika popularizēta humāna attieksme un morālā ārstēšana garīgo slimību gadījumā. Šīs pārmaiņas vēsturē paz̄istamas kā Filipa Pinela reformas. Savukārt 19. gadsimtam un it sevišķi 20. gadsimta sākumam Rietumu pasaulē raksturīgs institucionalizētas psihiatrijas uzplaukums, kas medicīnas vēstures pētījumos skaidrots dažādi. Par tā iemesliem tiek minēti zinātniskie sasniegumi psihiatrijā un psihiatrijas kā akadēmiskas disciplīnas attīstība, industrializācijas un urbanizācijas sekas, kā arī likumdošanas izmaiņas nolūkā nodrošināt vidusslāņa vēlmi pēc kārtības un drošības. ${ }^{1}$

Krievijas impērijā pirmos mēǵinājumus valstiski organizētas psihiatriskās aprūpes tīkla izveidē veica Katrīna II, 1775. gadā izdodot speciālu likumu, kas paredzēja guberṇās dibināt Sabiedriskās aizgādības kolẹgijas, kuru pienākumos ietilpa celt īpašas dziedniecības iestādes vājprātīgajiem. ${ }^{2}$

1 Dorries A., Beddies T. The Wittenauer Heilstatten in Berlin: A case record study of psychiatric patients in Germany, 1919-1960 / The Confinement of the Insane. International perspectives (1800-1965). / Ed. Porter. - Cambridge: R. \& Wright, 2003. - Pp. 149-172.

2 Buduls H. Latvijas galvas pilsētas Rīgas Sarkankalna slimnīcas vēsture 1862.-1937. - Rīga: Pilsētas valdes izdevums, 1938. - 5. lpp. 
1824. gadā Vidzemes guberņas Sabiedriskās aizgādības kolēgija Rīgā nodibināja Aleksandra Augstumu iestādi, kurā viena nodaļa bija paredzēta ar̄̄ garīgi slimo izvietošanai. ${ }^{3}$ Arī Kurzemē, Jelgavā, 1824. gadā tika dibināta Sabiedriskās aizgādības kolēgijas slimnīca, kurā viena nodaḷa atvēlēta garīgi slimiem pacientiem. ${ }^{4}$ Medicīniskais posms Latvijas psihiatrijā nosacīti iesākās ar Sarkankalna slimnīcas dibināšanu Rīgā (1862., sākotnēji privāta, bet no 1872. gada - pilsētas îpašumā), ${ }^{5}$ jo, atšķkirībā no iepriekš uzskaitītajām, š̀̃ slimnīca tika veidota tikai un vienīgi psihiatrisko slimnieku ārstēšanai. Nākamajos gados Latvijas teritorijā tika izveidotas vēl vairākas psihiatriskās aprūpes iestādes - Tabors (1887) un Ģintermuižas slimnīca (1901) Jelgavā (abas apvienoja 1921. gadā) ${ }^{6}$ un psihiatriskā slimnīca Strenčos (1907). ${ }^{7}$ Psihiatriskai ārstēšanai tika atvērtas arī nodaļas somatiskās slimnīcās Kuld̄̄gā (1890-1908 vai 1909) ${ }^{8}$ un Liepājā (1904). ${ }^{9}$ Nelielu skaitu maksātspējīgu pacientu aprūpēja ārstiem Šēnfeldiem piederošās privātklīnikas Rīgā, Pārdaugavā, (1897) ${ }^{10}$ un Sokolovska privātklīnika Rīgā (1898-1918?). ${ }^{11}$

Lai gan 19. gs. beigās Krievijas impērijā, tostarp arī Latvijas teritorijā, cita pēc citas tika atvērtas psihiatriskās slimnīcas, mentālo sasirgšanu

${ }^{3}$ Kuzņecovs V. 19. gs. pirmās puses valsts iestādes garīgi slimiem Latvijā: Aleksandra Augstumu personāls un pacienti. - I daḷa: Personāls. - LU raksti. Zinātṇu vēsture un muzejniecība. - Nr. 738, 2008. - 78.-97. lpp.

${ }^{4}$ Neubergs K. Ģintermužas slimnīca (1887.-1937. g.): Rakstu sakopojums Ģintermuižas slimnīcas (dib. 1887. gada 3. jūnijā) 50 gadu darbības atcerei. - Jelgava: Tautas labklājības ministrijas Veselības departamenta Ģintermuižas slimnīca, 1938. - 5.-8. lpp.

5 Buduls H. Latvijas galvas pilsētas Rīgas Sarkankalna slimnīcas vēsture 1862.-1937. - Rīga: Pilsētas valdes izdevums, 1938. - 102. lpp.

${ }^{6}$ Neubergs K. Ģintermužas slimnīca (1887.-1937. g.): Rakstu sakopojums Ģintermuižas slimnīcas (dib. 1887. gada 3. jūnijā) 50 gadu darbības atcerei. - Jelgava: Tautas labklājīibas ministrijas Veselības departamenta Ģintermuižas slimnīca, 1938. - 5.-8. lpp.

7 Vīksna A. Psihiatrijas saknes Latvijā // Latvijas Ārsts, 2003; 10: 7.-9. lpp.

8 LVVA, 4578. f., 4. apr., 207. 1., 21. 1p.

9 Sieberts H., Jēkabsons K. Ziṇas par Liepājas pilsētas slimnīcas psīchiatrisko un neiroloğisko nodaļu // Latvijas Ārstu Žurnāls, 1933; 4: 289. lpp.

10 Zalcmanis R. u. c. Rīgas ielas. - 1. sēj. - Rīga: Apgāds "Priedaines", 2001. 195.-196. lpp.; Vatere E. Ebreji - mediķi Latvijā 1918-1996. - Rīga: Latvijas Medicīnas akadēmija, 1997. - 78. lpp.

11 Vīksna A. Psihiatrijas saknes Latvijā // Latvijas Ārsts, 2003; 10: 8. lpp. 
gadījumos aizvien pārliecinoši dominēja mājas un kopienas aprūpe. Vēl 20. gadsimta sākumā, Nikolaja II vald̄̄šanas laikā, stacionēto psihiatrisko pacientu skaits bija niecīgs un vērā neņemams, salīdzinot ar impērijas skaitliski lielo populāciju. ${ }^{12}$

Latvijā situācija main̄ijās pēc Pirmā pasaules kara, Latvijas Republikas laikā, kad industrializācijas un urbanizācijas dēl veidojās citāda attieksme pret garīgām slimībām un pret psihiatrijas institūciju kopumā, rezultātā tradicionālās mājas aprūpes vietā aizvien biežāk stājās ārstēšana medicīniskā iestādē. Šīs pārmaiņas radīja vēl nebijušu pieprasījumu pēc medicīniskās palīdzības garīgo traucējumu gadījumā.

\section{Psihiatriskās aprūpes organizēšana Latvijas Republikā}

Iedzīvotāju veselības aizsardzība vienmēr bijusi cieši saistīta ar valsts sociālo politiku. Īpaši tas attiecināms uz psihiatrisko pacientu aprūpi, jo tieši viņiem visbiežāk nepieciešama ne tikai medicīniskā, bet arī sociālā aprūpe. Jaunajā Latvijas valstī ar sociālo aprūpi sākotnēji nodarbojās pašvaldības. Šādu kārtību noteica 1918. gada nogalē Tautas padomes pieņemtais Latvijas pagastu satversmes pagaidu likums, kas paredzēja pašvaldībām pienākumu rūpēties par sociāli apgādājamiem pēc viņu dz̄̄vesvietām. ${ }^{13}$ 1918. gada decembrī tika uzsākta Sociālā departamenta izveide, ${ }^{14}$ kuru 1920. gadā pārveidoja par Darba ministriju. ${ }^{15}$ Savukārt pirmā institūcija, kas nodarbojās ar veselības aizsardzības jautājumu risināšanu Latvijas valstī, bija 1919. gada 6. martā Liepājā nodibinātā Iekšlietu ministrijas Kurzemes medicīniskā pārvalde. ${ }^{16}$ Tās uzdevumos sākotnēji ietilpa galvenokārt lipīgo sērgu apkarošana un iedzīvotāju apgāde ar ārstniecības līdzekḷiem, kā arī apriņķu ārstu tīkla izveide. ${ }^{17}$

12 Dowbiggin I. The Quest for mental health: A Tale of science, scandal, sorrow, and mass society. - New York: Cambridge University Press, 2011. - Pp. 72-75.

13 Bērziņš V. (red.) 20. gadsimta Latvijas vēsture, II, Neatkarīgā valsts 1918.-1940. Rīga: Latvijas vēstures institūta apgāds, 2003. - 530.-533. lpp.

14 Turpat.

15 Vēsture. Latvijas Republikas Labklājības ministrijas mājaslapa. Pieejams: http:// www.lm.gov.lv/text/73 (sk. 03.09.2012.).

16 Bērziņš V. (red.) 20. gadsimta Latvijas vēsture, II, Neatkarīgā valsts 1918.-1940. Rīga: Latvijas vēstures institūta apgāds, 2003. - 540.-542. lpp.

17 Emersons K. Veselības departamenta administratīivi sanitārās nodaļas darbība // Tautas Labklājības Ministrijas Mēnešraksts, 1938; 10: 820. lpp. 

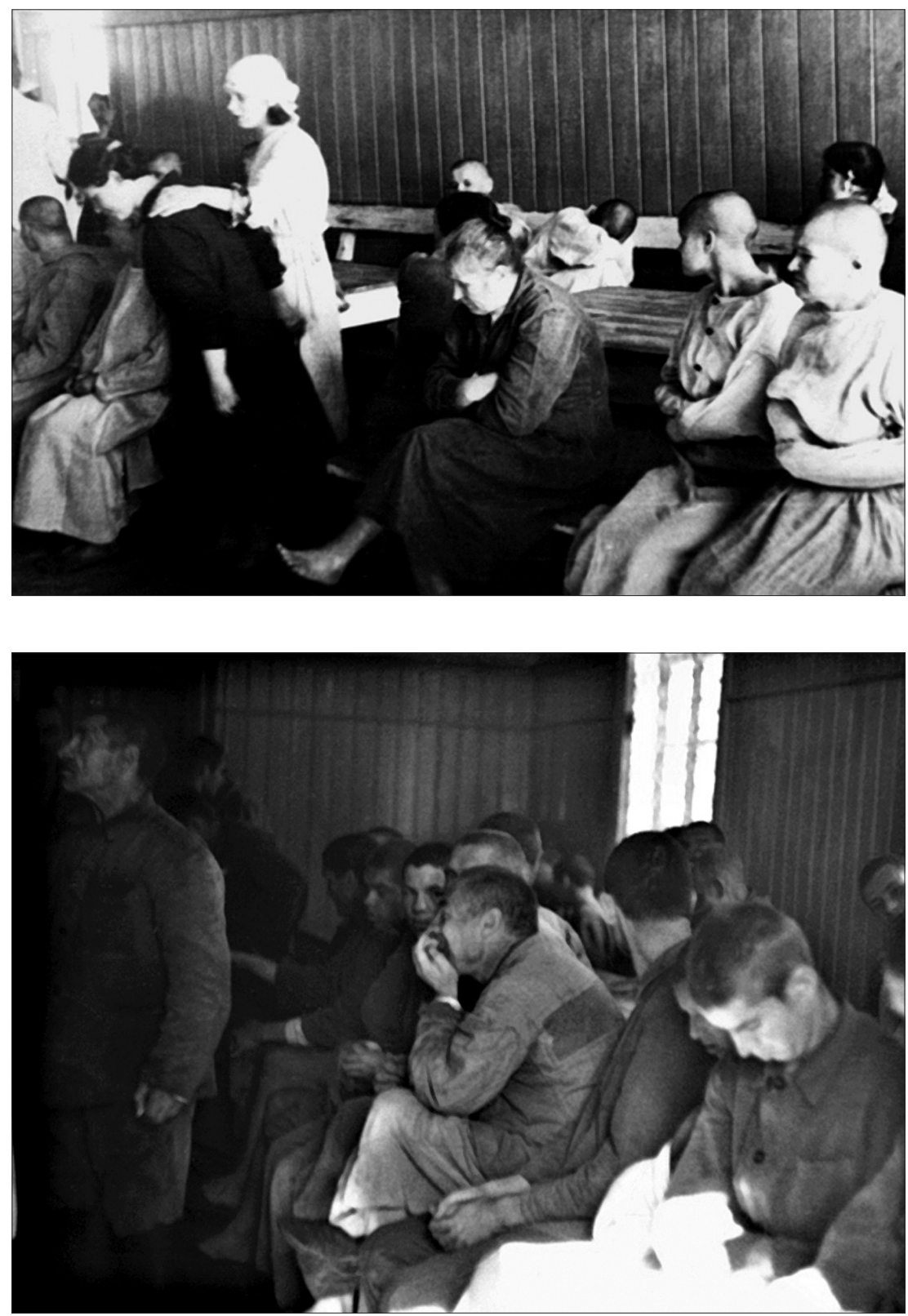

Ģintermuižas slimnīcas hronisko pacientu dienas telpas, 20. gs. 30. gadi 
1919. gada augustā, neilgi pēc Latvijas likumīgās valdības atgriešanās Rīgā, Kurzemes medicīniskā pārvalde tika pārveidota par Veselības departamentu, kas atradās Iekšlietu ministrijas pakḷautībā un bija augstākā ārstniecības un sanitāro lietu pārraudzības iestāde. ${ }^{18}$ Vēlāk, 1925. gadā, Iekšlietu ministrijas Veselības departamentu pievienoja Darba ministrijai un jaunizveidoto institūciju pārdēvēja par Tautas labklājības ministriju, ${ }^{19}$ kuras sastāvā esošais Veselības departaments bija galvenā veselības aprūpes pārvaldes institūcija līdz pat Otrajam pasaules karam.

1919. gada otrajā pusē un 1920. gada sākumā Veselības departaments savā pārzin̄ā pārṇēma slimnīcas un aprūpes iestādes, kas pirmskara gados strādāja psihiatriskās aprūpes jomā un pēc kara bija palikušas bez finansējuma. Veselības departaments pārņēma Vidzemes bruņniecības celto slimnīcu Strenčos, Vidzemes guberņas Sabiedriskās aizgādības Aleksandra Augstumu slimnīcu Rīgā, Kurzemes guberņas Sabiedriskās aizgādības slimnīcu "Stalı̣placis” Jelgavā (šeit galvenokārt atradās somatiskie slimnieki, bet daļa bija arī psihiatriskie pacienti), Kurzemes bruņniecības celto Ģintermuižas psihiatrisko slimnīcu Jelgavā un tai blakus atrodošos Kurzemes mācītāju sinodes dibināto iestādi "Tabor". 20 Drīz Jelgavas "Stallıplacis" ekonomisku apsvērumu dēl tika likvidēts, bet psihiatriskie slimnieki pārvietoti uz "Tabor” iestādi vai Ģintermuižas slimnīcu. ${ }^{21}$ Rīgas pilsētas Sarkankalna slimnīcu, kas jau pirmskara gados bija atradusies pilsētas īpašumā un Slimnīcu komisijas pārvaldībā, savā pārzin̄ā n̦ēma Rīgas pilsētas Veselības nodaļa, kas 1934. gadā tika pārdēvēta par Veselības valdi. ${ }^{22}$

Bez šīm trim Veselības departamenta slimnīcām un Rīgas pilsētas Sarkankalna slimnīcas ar psihiatrisko aprūpi Latvijā turpināja nodarboties arī psihiatriskā nodaḷa Liepājas pilsētas slimnīcā, ${ }^{23}$ kā arī

18 Pārskats par Iekšlietu ministrijas darbību mūsu valsts piecu gadu pastāvēšanas laikā // Policijas Vēstnesis, 1923. g. 20. nov.; 58: 2.-4. lpp.

19 Jaundzems S. Tautas labklājības ministrijas tapšana un tās darbības virzieni // Tautas Labklājības Ministrijas Mēnešraksts, 1938; 9: 706.-708. 1pp.

20 Emersons K. Veselības departamenta administratīivi sanitārās nodaḷas darbība // Tautas Labklājības Ministrijas Mēnešraksts, 1938; 10: 823. 1pp.

21 Turpat; LVVA, 4578. f., 4. apr., 207. 1., 21. lp.

22 Buduls H. Latvijas galvas pilsētas Rīgas Sarkankalna slimnīcas vēsture 1862.-1937. - Rīga: Pilsētas valdes izdevums, 1938. - 107. 1pp.

23 Pārskats par Iekšlietu ministrijas darbību mūsu valsts piecu gadu pastāvēšanas laikā // Policijas Vēstnesis, 1923. g. 20. nov.; 58: 2.-4. lpp. 
L. Šēnfelda privātklīnika Rīgā - pēdējās divas gan nodrošināja vien nelielu gultas vietu skaitu. Vēlāk, 1924. gadā, tika izveidota Daugavpils psihiatriskā slimnīca, 1933. gadā - A. Šēnfelda privātklīnika "Atgāzene", 1934. gadā - psihiatriskā nodaḷa Rīgas 2. slimnīcā, bet 1936. gadā Mellera privātklīnika. ${ }^{24}$

Visā starpkaru periodā valsts psihiatriskās slimnīcas atradās Veselības departamenta pārzin̄ā, turklāt jāpiebilst, ka tās arī bija vien̄̄gās Veselības departamenta slimnīcas. Bez tām Veselības departamenta pārziṇā bija vēl leprozoriji un veselības avotu iestādes. ${ }^{25}$

\section{Psihiatrisko pacientu skaita pieaugums}

Tūlìt pēc kara valdīja maldīgs priekšstats, ka psihiatrisko slimnīcu paplašināšana nav nepieciešama un nekādām problēmām ar garīgi slimo stacionēšanu nevajadzētu rasties - tobrīd esošās psihiatriskās slimnīcas bija pustukšas. 1920. gada janvārī Strenču, Ģintermuižas, Aleksandra Augstumu slimnīcās, "Tabor" iestādē un Rīgas pilsētas Sarkankalna slimnīcā kopumā atradās ap 1050 pacientu. ${ }^{26}$ Tobrīd gultas vietu skaits psihiatriskajās slimnīcās ievērojami pārsniedza pacientu skaitu stacionāros.

Šāda slimnīcu nenoslogotība bija radusies tāpēc, ka kara gados trūcīgo apstākḷu, bada un epidēmiju dēḷ liels skaits psihiatrisko iestāžu pacientu nomira. Latvijas Universitātes Psihiatrijas katedras vadītājs un Rīgas pilsētas Sarkankalna slimnīcas direktors Hermanis Buduls (1882-1954) pēckara situāciju aprakstīja, sakot, ka "kara gados slimnīcas iemītnieki cieta arī no epidēmijām: influencas, asinssērgas, tīfa u. c., laikiem arī no pārtikas trūkuma. Kara un juku laika beigās slimnieku nodaļas bija

24 Tautas veselības statistika 1932. un 1933. - Rīga: Valsts statistiskā pārvalde, 1935. - 52.-53. lpp.; Tautas veselības statistika 1934. - Rīga: Valsts statistiskā pārvalde, 1936. - 71. lpp.; Tautas veselības statistika 1936. - Rīga: Valsts statistiskā pārvalde, 1937. - 83. lpp.

25 LVVA, 4578. f., 208. 1., 3.-5. lp. (Veselības departamenta pārskats par 1920. gadu); Emersons K. Veselības departamenta administratīvi sanitārās nodaḷas darbība // Tautas Labklājības Ministrijas Mēnešraksts, 1938; 10: 827.-828. lpp.

26 Aprēķināts no: LVVA, 4578. f., 4. apr., 208. 1., 10.-11. 1p.; Emersons K. Veselības departamenta administratīvi sanitārās nodaḷas darbība // Tautas Labklājīibas Ministrijas Mēnešraksts, 1938; 10: 823.-825. lpp.; Rīgas pilsētas statistiskā gada grāmata 1920.-1922. - Rīga, 1923. - 101. lpp. 
palikušas patukšas, un dažas no tām bija uz laiku jāslēdz". ${ }^{27}$ Tā, piemēram, 1921. gadā Sarkankalna slimnīcā vienu psihiatrisko slimnieku nodaḷu slēdza, un tās telpās ierīkoja tuberkulozes slimnieku nodaļu, kura tur darbojās līdz 1926. gadam. ${ }^{28}$ Savukārt Aleksandra Augstumu slimnīcā nepietiekamas ēdināšanas dēḷ slimnieku mirstība 1917. gadā sasniedza $35 \%$, bet 1918. gadā $-45 \% .{ }^{29}$ Strenču slimnīcā pacientu skaits, kas pirmskara gados bija pieaudzis līdz 305 cilvēkiem, kara laikā uztura līdzekḷu trūkuma, slimnieku izstāšanās dēḷ, kā arī daudziem nomirstot no lipīgām slimībām un sliktas ēdināšanas dēl, bija samazinājies līdz 132 pacientiem. ${ }^{30}$ Nelielais stacionāra slimnieku skaits radīja maldīgu iespaidu, ka psihiatrisko slimnīcu paplašināšanas jautājums nav aktuāls.

Tāpēc pirmajos pēckara gados Veselības departamenta prioritātes bija sanitāro apstākḷu uzlabošana un uzraudzība, cīṇa ar lipīgām slimībām, starptautisko sanitārtiesību nokārtošana un departamentam padoto iestāžu pārorganizēšana. ${ }^{31}$ Finansiālu apsvērumu dēl Veselības departaments atteicās no vairāku citu savu nodomu realizēšanas, tostarp "garā vājo jautājuma nokārtošanas visplašākos apmēros" - "šos nodomus cer pakāpeniski realizēt, piemērojoties valsts materiāliem apstākḷiem un tam nolūkam atvēlētiem kredītiem". 32

Tomēr jau nākamie pēckara gadi parādīja, ka psihiski slimo cilvēku skaits, kam nepieciešama ārstēšana slimnīcā, sāka strauji pieaugt. Jau 1922. gada maijā Iekšlietu ministrija mēǵināja problēmu risināt, izveidojot ārstu psihiatru komisijas, kuru uzdevums bija noskaidrot valsts slimnīcās ievietoto pacientu veselības stāvokli un noteikt atsevišķiem slimniekiem turpmāko nepieciešamību un lietderību tajās atrasties. Slimniekus, kurus šīs ārstu komisijas atzina par izārstētiem vai apkārtni neapdraudošiem un kuriem slimnīcā turpmāka uzturēšanās nebija vajadzīga, plānoja no slimnīcām izrakstīt, nododot tos attiecīgu pašvaldības

27 Buduls H. Latvijas galvas pilsētas Rīgas Sarkankalna slimnīcas vēsture 1862.-1937. - Rīga: Pilsētas valdes izdevums, 1938. - 79.-80. 1pp.

28 Turpat, 80.-81. lpp.

29 Brants J. Aleksandra Augstumu slimnīca 1824.-1924 // Latvijas Ārstu Žurnāls, 1925; 1/2: 5 . 1pp.

30 LVVA, 4578. f., 4. apr., 207. 1., 2. 1p.

31 Pārskats par Iekšlietu ministrijas darbību mūsu valsts piecu gadu pastāvēšanas laikā // Policijas Vēstnesis, 1923. g. 20. nov.; 58: 2.-4. lpp.

32 LVVA, 4578. f., 4. apr., 211. 1., 1.-5. 1p. 
iestāžu apgādībā pēc slimnieka agrākās dzīvesvietas. ${ }^{33}$ Tomēr šis mēǵinājums nedeva jūtamus rezultātus. 1923. gadā - pēc Iekšlietu ministrijas piecu gadu darbības pārskata redzams - četras lielās psihiatriskās slimnīcas un psihiatriskā nodaḷa Liepājas slimnīcā, kuras nodrošināja 1225 gultas vietas garīgi slimo pacientu uzņemšanai, bija pārpildītas, un no jauna saslimušie pacienti bieži bija jāatraida. Ziņojumā, atsaucoties uz citu Rietumeiropas valstu pieredzi, kur uz 500 līdz 600 iedzīvotājiem bija paredzēta viena gultas vieta psihiatriskā stacionārā, tika aprēķināts, ka Latvijā būtu nepieciešamas vismaz 2500 gultas vietas psihiatrisko slimību pacientiem. Tāpēc 1923. gadā, uzsākot savu piekto darbības gadu un konstatējot arvien lielāko saspīlējumu psihiatriskās aprūpes jomā, Veselības departaments par prioritāro uzdevumu izvirzīja esošo psihiatrisko slimnīcu paplašināšanu un jaunas psihiatriskās dziednīcas celtniecību Daugavpilīi. ${ }^{34}$ Veselības departamenta direktors Jānis Kivickis vēstulē prezidentam Jānim Čakstem (1859-1927) skaidroja šo nepieciešamību: "Psichiski slimo un idiotu skaits Latvijā nesamērīgi liels un vairojas ik gadus. Sabiedrības labā tie, kā bīstami, būtu izolējami un apgādājami slimnīcās. Diemžēl speciālo slimnīcu skaits mums tik mazs, ka nespējam pat ne pusi no visiem apgādājamiem novietot. Latgalē pat nav nevienas šādas iestādes, kurp sūtīt šos nelaimīgos." 35 Pirms slimnīcas atvēršanas, kā rakstīja vietējais Daugavpils laikraksts, situācija Latgalē garīgi slimo aprūpē esot bijusi l̦oti slikta. Par to liecinot tas, ka "Varkavas pagastā kāds vājprātīgais vēl nepilni 2 gadi atpakal pie bluķa pieķēdēts, bet Galumuižā kāds vecticībnieks ieslodzīts krātiņāa."36

Daugavpils psihiatriskā slimnīca ar 100 gultas vietām ${ }^{37}$ tika atvērta 1924. gada oktobrī. Paplašinoties arī pārējām slimnīcām un pieskaitot lielāko privātklīniku - Šēnfelda iestādi -, 1924. gadā psihiatriskajai aprūpei bija pieejamas jau 1635 gultas vietas. ${ }^{38}$ Tomēr jau 1925. gadā - pēc Veselības

33 LVVA, 4578. f., 4. apr., 211. 1., 1.-5. 1p.

34 Pārskats par Iekšlietu ministrijas darbību mūsu valsts piecu gadu pastāvēšanas laikā // Policijas Vēstnesis, 1923. g. 20. nov.; 58: 2.-4. lpp.

35 LVVA, 4578. f., 4. apr., 211. 1., 68. 1p.

36 Daugavpils psichiatriska slimnīca // Daugavas Vārds, 1926. g. 24. dec.; 43: 2.-3. lpp.

37 Hellmann E. Die neue psychiatrische Heilanstalt in Dünaburg / I Latvijas Ārstu un zobārstu kongresa darbi. - Rīga: Kongresa izpildu komitejas izdevums, 1926. - 455.-458. lpp.

38 Tautas veselības statistika 1929. - Rīga: Valsts statistiskā pārvalde, 1930. - 32. lpp. 
departamenta aprēķiniem - ārpus slimnīcām atradās vēl 1536 garā vāji cilvēki, no kuriem 193 tika vērtēti kā "bīstami apkārtnei” un noteikti būtu ievietojami slimnīcās. ${ }^{39}$ Tāpēc arī nākamajos gados slimnīcas tika pakāpeniski paplašinātas un labiekārtotas. 1929. gadā gultas vietu skaits psihiatriskajiem pacientiem sasniedza $2364,{ }^{40}$ 1935. gadā $-2710,{ }^{41}$ bet 1938. gadā uz teju divu miljonu lielo Latvijas populāciju bija 3048 gultas vietas. $^{42}$ Kaut arī notika slimnīcu paplašināšana, arī 20. gs. 30. gadu otrā pusē gultas vietu skaits psihiatriskajiem pacientiem Latvijā salīizinājumā ar dažām citām Eiropas valstīm (Nīderlandi, Šveici) aizvien bija pat divas reizes mazāks. Turpretī Latvijas kaimiņvalstī Lietuvā, tāpat kāa Polijā, gultu skaits bija proporcionāli daudz mazāks nekā Latvijā. ${ }^{43}$ Lietuvā 1937. gadā bija tikai 500 šādu gultas vietu uz vairāk kā diviem ar pusi miljoniem iedzīvotāju, un tur gada laikā tika uzñemti 429 slimnieki. ${ }^{44}$ Raugoties no mūsdienu viedokḷa, psihiatriskajā aprūpē gultas vietu skaits Latvijā starpkaru periodā bija liels. Taču jāuzsver, ka 20. gs. 20.-30. gados pirms antipsihotisko medikamentu ēras sākuma slimnieki stacionārā pavadīja daudz ilgāku laiku, un ambulatorās aprūpes programma faktiski nebija istenojama.

Ja 20. gadsimta 20. gadu sākumā Latvijā psihiatriskajās slimnīcās bija stacionēti ap 1200 pacientu, ${ }^{45}$ tad 30. gadu beigās stacionēto pacientu skaits bija pieaudzis vairāk nekā 2,5 reizes. ${ }^{46}$ Salīdzinājumam -

39 Pētersons A. Veselības stāvoklis Latvijā // Tautas Veselība, 1927; 1: 1.-4. lpp.

40 Tautas veselības statistika 1929. - Rīga: Valsts statistiskā pārvalde, 1930. - 32. lpp.

${ }^{41}$ Tautas veselības statistika 1935. - Rīga: Valsts statistiskā pārvalde, 1936. - 76.-77. 1pp.

42 Tautas veselības statistika 1938. - Rīga: Valsts statistiskā pārvalde, 1940. - 72.-73. 1pp.

43 Neubergs K. Psīchiatriskās slimnīcas, to darbība, uzdevumi un viedokḷi: Rakstu sakopojums Ģintermuižas slimnīcas (dib. 1887. gada 3. jūnijā) 50 gadu darbības atcerei. - Jelgava: Tautas labklājības ministrijas Veselības departamenta Ģintermuižas slimnīca, 1938. - 13.-24. lpp.

Lietuvas Tautas veselības pārskats // Tautas Labklājības Ministrijas Mēnešraksts, 1940; 1: 38.-39. lpp.

45 Pārskats par Iekšlietu ministrijas darbību mūsu valsts piecu gadu pastāvēšanas laikā // Policijas Vēstnesis, 1923. g. 20. nov.; 58: 2.-4. lpp.

46 Tautas veselības statistika 1938. - Rīga: Valsts statistiskā pārvalde, 1940. - 72.-73. lpp. 
iedzīvotāju skaits Latvijā pēc tautas skaitīšanas datiem no 1920. līdz 1935. gadam bija pieaudzis tikai par apmēram 22\%.47 Tāpēc rodas jautājums - kāds bija iemesls tik krasam uz stacionēšanu pretendējošo pacientu pieaugumam starpkaru periodā?

\section{Psihiatrisko pacientu skaita pieauguma iemesli}

Publiskajā telpā valdīja uzskats, ka pārciestās kara šausmas, trūkums, alkoholisms un inficēšanās ar veneriskajām slimībām kara gados ir cēlonis straujam psihisko slimību pieaugumam. 1923. gadā veselības departamenta direktors Jānis Kivickis un iekšlietu ministrs Pēteris Berğis (1882-1942) vēstulē Ministru kabinetam skaidroja nepieciešamību piešķirt papildu finansējumu psihiatriskai aprūpei: "Kara sistās brūces pārāk dziḷas, lai tās sadziedētu ar mūsu nabadzīgajiem līdzeklịiem, tautas dvēsele slima un vāja, tā meklē acumirklīgu pacilātību postu nesošos apdullināšanās līdzekḷıs: alkoholā, morfijā un kokaīnā, kuri kopā ar plaši izplatītām veneriskām slimībām deǵenerē tautu uz augumiem un bīstamā kārtā vairo miesīgo un garīgo kropḷu skaitu." ${ }^{\prime 4}$

Līdzīgi sprieda arī Saeimas deputāti. 1926. gadā sociāldemokrāts Roberts Bīlmanis (1880-1964) savā uzrunā Saeimas sēdē apgalvoja, ka līdz pat $80 \%$ psihiatrisko slimnīcu pacientu tur nokḷuvuši alkoholisko dzērienu lietošanas "normālā un nenormālā veidā" dẹḷ.49 Līdzīgi 1927. gadā Saeimā runāja arī Kristīgās nacionālās apvien̄ības deputāts, ārsts Gustavs Reinhards (1868-1937), uzsverot, ka, pirmām kārtām, psihiatriskās slimnīcas pārpildot alkoholiķi, bet, otrām kārtām, - "veneriķi". 50 Savukārt sociāldemokrātu deputāts Kārlis Būmeisters (1888-1967)

47 Aprēķins veikts pēc LR Centrālā statistikas biroja publicētajiem datiem. Pieejams: http://www.csb.gov.lv/statistikas-temas/iedzivotaji-skaits-un-blivumstema-32579.html (sk. 03.09.2012.).

48 LVVA, 4578. f., 4. apr., 211. 1., 47. lp.

${ }^{49}$ Latvijas Republikas II Saeimas II sesijas 6. sēde 1926. gada 19. februārī. Latvijas Republikas II Saeimas stenogrammas. II sesija. 1926. gads. - Rīga: Latvijas Republikas Saeimas izdevums, 1926. - 178. sl.

50 Latvijas Republikas II Saeimas VI sesijas 11. sēde 1927. gada 13. maijā. Latvijas Republikas II Saeimas stenogrammas. VI sesija. 1927. gads. - Rīga: Latvijas Republikas Saeimas izdevums, 1927. - 179. sl. 
Saeimas sēdē paziņoja, ka "vājprātība daudzos gadījumos ir liela trūkuma sekas, arī bezdarba un pārdzīvoto kara šausmu sekas. Nervu satricinājumi un vispār daudzi citi pēdējo gadu smagie pārdzīvojumi ir veicinājuši vājprātību". ${ }^{51}$

Šie apgalvojumi, kas izteikti, Saeimas deputātiem diskutējot par valsts atbildību sociālās apgādības laukā, protams, bija polemiski un nepamatoti. Zināmā mērā jāpiekrīt, ka saslimstības ar sifilisu pieaugums kara gados ${ }^{52}$ vēlāk radīja arī progresīvās paralīzes (vēlīnu sifilisa komplikāciju) pacientu skaita pieaugumu stacionāros. Zināms, ka Sarkankalna slimnīcā progresīvās paralīzes pacientu skaits maksimumu sasniedza 1934. gadā, kad ar šādu diagnozi stacionārā bija 14,8\% no visu pacientu kopskaita. ${ }^{53}$ Tomēr, kopumā ņemot, tā nepavisam nebija biežāk sastopamā diagnoze psihiatriskajās slimnīcās. Pēc Veselības departamenta zin̄ām psihiatriskajās slimnīcās ar diagnozi dementia paralytica et lues cerberi no 1927. līdz 1938. gadam ārstējās ap 6\% pacientu. ${ }^{54}$ Procentuāli vēl mazāks skaits pacientu atradās stacionāros ar diagnozēm, kas tieši saistītas ar alkohola lietošanu. Pacientu skaits, kas stacionārā atradās hroniska alkoholisma, delirium tremens un citu alkoholisma psihožu dēl, šajā laikā bieži nesasniedza pat pusprocentu. ${ }^{55}$ Jāpiebilst, ka ar alkohola lietošanu saistīto pacientu kustība psihiatriskajos stacionāros bija salīdzinoši ātrāka, šie pacienti stacionāros varēja nonākt atkārtoti, bet slimnīcās neuzturējās ilgi. Nenoliedzami, ka biežākā diagnoze psihiatriskajos stacionāros bija dementia praecox jeb jaunības plānprātība, kas nemainīgi pārsniedza $60 \%$ no stacionāros esošo pacientu

${ }^{51}$ Latvijas Republikas III Saeimas IV sesijas 10. sēde 1929. gada 22. novembrī. Latvijas Republikas III Saeimas stenogrammas. Ārkārtējā un IV sesija. 1929. gads. - Rīga: Latvijas Republikas Saeimas izdevums, 1929. - 494. sl.

52 Miltiņš A., Vasariņš P. Klīniskā dermatovenerolog̣ija. - Rīga: Zvaigzne ABC, 1999. - 391.-394. lpp.

53 Buduls H. Latvijas galvas pilsētas Rīgas Sarkankalna slimnīcas vēsture 1862.-1937. - Rīga: Pilsētas valdes izdevums, 1938. - 192. lpp.

54 Aprēķināts no: Tautas veselības statistiska 1927., 1928., 1929., 1930., 1931., 1932., 1933., 1934., 1935., 1936., 1937., 1938. g. Aprēķini izdarīti, attiecinot stacionāros esošo pacientu skaitu ar diagnozi dementia paralytica et lues cerebri pret kopējo psihiatriskos stacionāros esošo pacientu skaitu gada sākumā.

55 Turpat. Aprēķini izdarīti, attiecinot stacionāros esošo pacientu skaitu ar diagnozēm: hronisks alkoholisms, delirium tremens u. c. alkohola psihozes pret kopējo psihiatriskos stacionāros esošo pacientu skaitu gada sākumā. 
kopskaita. ${ }^{56}$ Šie skaiții rāda, ka pacientu skaita pieaugums stacionāros nav izskaidrojams tikai ar alkoholisma un seksuāli transmisīvo slimību sekām.

To, ka slimnīcu pārpildīšanās iemesli meklējami pavisam citur, skaidri apzinājās psihiatri. Viņi uzskatīja, ka saslimstības pieaugums ir tikai šķietams un kopumā slimnieku skaits ir saglabājies aptuveni tāds pats kā pirms kara, bet pacientu pieplūdums psihiatriskajos stacionāros saistāms galvenokārt ar sociālajiem apstākḷiem un sabiedrības pārorientēšanos uz industrializētas sabiedrības modeli.

Ģintermuižas slimnīcas direktors Kristaps Neibergs (1875-1950) arvien pieaugošo pieprasījumu pēc vietām psihiatriskajās slimnīcās pēckara gados raksturoja šādi:

"Ne jau tamdēl, ka būtu radušies uzplūdi garīgā saslimšanā. Bet dzīves apstākḷi ǵimenēs, kā uz laukiem, tā pilsētās, bija grozījušies, un vājprātīgie traucēja pārējos ǵimenes locekḷus darbā un dzīvē. Pie dzīves atjaunošanas bija jāķeras ar lielāku sparu, un tamdēḷ visi mēǵināja atkratīties no liekēžiem un traucējumiem. Arī patriarchālais dzīves uzskats bija ņēmis citu virzienu, un vājprātīgie ar savām traucētajām piemērošanās spējām vairs nevarēja nekādi ierindoties jaunajos apstākḷos un piemēroties ikdienišksīgajā dzīvē., ${ }^{57}$

20. gs. 30. gados mainījās arī attieksme pret psihiatriju kopumā, jo tā no uzraugošas un uzvedību koriǵējošas jomas pamazām pārveidojās par leǵitīmu medicīnas nozari. ${ }^{58}$ Tāpēc arī sabiedrība no psihiatriskām slimnīcām nevairījās tik ļoti kā iepriekš un sāka aprast ar domu, ka psihiskie traucējumi ir slimība, kas jāārstē, nevis kauna zīme, ko jācenšas turēt noslēpumā: "Agrāk daudzi piederīgie savus slimos slēpa un pat turēja ieslodzītus atsevišksāa mājas telpās... Tādas dzīves parādības, ka garīgi slimie

56 Aprēķināts no: Tautas veselības statistiska 1927., 1928., 1929., 1930., 1931., 1932.-1933., 1934., 1935., 1936., 1937., 1938. g. Aprēķini veikti, attiecinot stacionāros esošo pacientu skaitu ar diagnozi dementia praecox pret kopējo psihiatriskos stacionāros esošo pacientu skaitu gada sākumā.

57 Neubergs K. Ģintermužas slimnīca (1887.-1937. g.): Rakstu sakopojums Ģintermuižas slimnīcas (dib. 1887. gada 3. jūnijā) 50 gadu darbības atcerei. - Jelgava: Tautas labklājīibas ministrijas Veselības departamenta Ģintermuižas slimnīca, 1938. - 8. lpp.

${ }^{58}$ Libiete I. Fighting schizophrenia: Beginnings of somatic treatments in psychiatry in Riga Sarkankalns hospital in the 1930s // Baltic Journal of European Studies, 2011; 1 (9): 257-268. 
noplīsuši un izbadējušies klaiņo apkārt kā antiņi, pirmskara gados bija katrā pagastā, un arī tādas parādības, ka garīgi slimos turēja ķēdēs saistītus kūtīs kopā ar lopiem, dienu no dienas kḷūst retākas."59

Psihiatrijas medikalizācijas process mazināja psihiatrisko stigmu un iedrošināja cilvēkus meklēt palīdzību pie ārstiem psihiatriem. Taču ārsti aizrādīja arī uz pārāk lielo entuziasmu, ar kādu cilvēki centās atbrīvoties no saviem slimajiem un par traucēkli kḷuvušajiem tuviniekiem, mēǵinot tos pēc iespējas ātrāk ievietot slimnīcā, pirms tam nekonsultējoties ar speciālistiem un neizvērtējot mājas aprūpes iespējas. Aprakstīti pat absurdi gadījumi, ka uz psihiatrisko slimnīcu atvests arī trīsgadīgs bērns ar garīgu atpalicību, jo radinieki viņu uzskatījuši par sabiedrībai bīstamu, “aizmirstot, ka arī normāls 3. g. vecs bērns, spēlējoties ar uguni, var nodedzināt ēku un kḷūt "sabiedrībai bīstams". Tāds bērns ar valdības piemaksu var l̦oti labi dzīvot ǵimenes kopšanā, jo iestādē tas nav ārstējams, bet tikai pavairo to invalīdu skaitu, no kuriem slimnīca netiek brīva gadu desmitiem". ${ }^{60}$

Papildu vispārējai attieksmes pret psihiatriju maiņai, otrs iemesls pieprasījuma pieaugumam pēc psihiatrijas stacionāriem bija meklējams arī tīri ekonomiskas dabas apsvērumos. Pacientiem, salīizinot ar pirmskara gadiem, bija vienkāršāk iekḷūt psihiatriskajā slimnīcā un tur ilgāk uzturēties, jo ārstēšanas izdevumi, kas pirmskara gados lielākajā daļā gadījumu gūlās uz pašu slimnieku vai viṇu tuvinieku pleciem, galvenokārt tika segti no valsts, pašvaldību vai slimokasu līdzekḷiem. 20. gs. 20. un 30. gados par saviem līdzekḷiem ārstējās tikai niecīga psihiatrisko pacientu daļa. 1927. gadā, piemēram, uz sava rēķina, segdami atbilstīgi noteikumiem trešdalıu ārstēšanas izdevumu, Sarkankalna slimnīcā ārstējās 13\%, Ģintermuižā - 18\%, Strenčos - 15\%, Aleksandra Augstumu slimnīcā - 8\%, bet Daugavpils slimnīcā - 7,5\% pacientu. ${ }^{61}$ 1939. gadā Aleksandra Augstumu iestādē neārstējās neviens pacients, kas segtu ārstēšanas izmaksas noteiktās maksas apmērā, aptuveni 7\% no gultas dienu izmaksām sedza samazinātos apmēros, pārējie ārstējās uz valsts, pašvaldību vai slimokasu

59 Laksbergs A. Rūpēs par garīgi slimiem. Kāpēc pārpildītas psichiatriskās slimnīcas? // Latgales Vēstnesis, 1938. g. 28. mar.; 34: 4. 1pp.

${ }^{60}$ Laksbergs A. Rūpes par garīgi slimiem. Kāpēc pārpildītas psichiatriskās slimnīcas (Beigas)? // Latgales Vēstnesis, 1938. g. 30. mar.; 35: 2. lpp.

${ }^{61}$ Buduls H. Par garīgi slimo apgādību Latvijā // Latvijas Ārstu Žurnāls, 1929; 7/8: 577. 1pp. 
rēķina. Daugavpilī ārstēšanas maksu pilnos apmēros sedza 0,49\% pacientu, samazinātu ārstēšanas maksu-2,67\%, pārējie tika ārstēti par valsts, pašvaldību un slimokasu naudu. Ģintermuižā 9,44\% gultas dienu tika segtas pilnos apmēros par pacientu līdzekl̦iem. Bet Strenčos tikai nedaudz vairāk par 1\%.62

Trešais - un visbūtiskākais - iemesls slimnieku pārblīvētībai stacionāros bija nesakārtota sociālā aprūpe. Slimnieku aprite psihiatriskajos stacionāros notika l̦oti lēni, jo pacientiem vienkārši nebija citas vietas, kur uzturēties. "No citām slimnīcām tie, kam nevar līdzēt, iet ārā, bet mums tomēr otrādi - tie paliek iekšā, dažreiz uz visu mūžu un pa lielākai daḷai uz ilgu ilgiem gadiem. Tā, piemēram, mums ir tādi slimnieki, kas atrodas 43 gadus, 42 gadus, 39 gadus, 38 utt.," intervijā laikrakstam atzina Ģintermuižas slimnīcas direktors K. Neibergs. ${ }^{63}$

\section{Psihiatrisko stacionāru pārslodze}

Lai apmierinātu pieaugošo pieprasījumu pēc psihiatriskā stacionāra, valsts un pašvaldību psihiatriskās slimnīcas nemit̄̄gi tika paplašinātas un labiekārtotas. Daugavpils psihiatriskā slimnīca, piemēram, no sākotnējām 100 gultas vietām 30. gadu beigās bija izaugusi par lielu slimnīcu ar 800 gultas vietām. ${ }^{64}$ No 1923. līdz 1938. gadam gultas vietu skaits Strenču slimnīcā bija pieaudzis no 250 līdz 365, Ģintermuižā - no 350 līdz 620, Sarkankalna slimnīcā - no 400 līdz 788. Aleksandra Augstumu slimnīcā pieaugums bija vismazākais - no 200 līdz 240 gultas vietām. ${ }^{65}$ Slimnīcas paplašināja, tām piebūvējot jaunus korpusus vai paplašinot nodaļas.

1934. gada vasarā ap 90 Aizgādības valdes uzturamo hronisku mierīgo slimnieku pārveda uz Rīgas 2. slimnīcu un ievietoja vienā no kara gados uzceltajām koka barakām, kur izveidoja psihiatrisko nodaļu, ${ }^{66}$

62 Aprēksināts no: Pārskats par Veselības departamenta darbību 1939. gadā // Tautas Labklājīibas Ministrijas Mēnešraksts, 1940; 4/5: 345.-351. lpp.

${ }^{63}$ Ģintermuižas slimnīcas izveidošanās (Beigas) // Zemgales Balss, 1937. g. 8. jūl.; 149: 6. lpp.

${ }^{64}$ Tautas veselības statistika 1938. - Rīga: Valsts statistiskā pārvalde, 1940. - 72. lpp.

${ }^{65}$ Pārskats par Iekšlietu ministrijas darbību mūsu valsts piecu gadu pastāvēšanas laikā // Policijas Vēstnesis, 1923. g. 20. nov.; 58: 2. lpp.; Tautas veselības statistika 1938. - Rīga: Valsts statistiskā pārvalde, 1940. - 72.-73. lpp.

66 Buduls H. Latvijas galvas pilsētas Rīgas Sarkankalna slimnīcas vēsture 1862.-1937. - Rīga: Pilsētas valdes izdevums, 1938. - 187. lpp. 
kas darbojās līdz 1942. gadam, ${ }^{67}$ nodrošinot 90 gultas vietas. ${ }^{68}$ Jāatzīmē, ka straujākais gultu skaita pieaugums, spriežot pēc Valsts statistiskās pārvaldes publicētajiem datiem, bija novērojams tieši 20. gs. 20. gados, vēlāk slimnīcu paplašināšanas temps nedaudz mazinājās.

Tomēr slimnīcu paplašināšana un labiekārtošana nespēja atrisināt galveno problēmu - nebija uz kurieni izrakstīt hroniskus mierīgos pacientus, un kāds deputāts Saeimas sēdē situāciju psihiatriskajās slimnīcās raksturoja ar vārdiem: "Visi koridori un visi kakti jau pilni vājprātīgo."69

1925. gada beigās, piemēram, kopumā psihiatriskajās slimnīcās uzturējās par aptuveni 3\% vairāk pacientu nekā to aţ̦āva reālais gultas vietu skaits. Šai slimnieku kategorijai (kam nebija savas gultas vietas) psihiatru vidū tika lietots apzīmējums "bezgultnieki”. Pieaugot gultas vietu skaitam, 1929. gadā viṇu skaits jau bija samazinājies līdz 1,6\%.70 Bet vēlāk, slimnīcu paplašināšanas tempam nedaudz mazinoties, 1935. gada nogalē bezgultnieku skaits sasniedza maksimumu - nedaudz vairāk kā desmitā daļa visu pacientu ietilpa bezgultnieku kategorijā. Nākamajos gados veiktā slimnīcu paplašināšana par vairāk kāa 300 vietām l̦āva 1938. gada nogalē bezgultnieku skaitu samazināt $1 \overline{1} \mathrm{dz} 6 \%{ }^{71}$

Šeit minētie skaiț̣i atspoguḷo situāciju kopumā, t. i., visās valsts un pašvaldību psihiatriskajās slimnīcās Latvijā. Taču ir būtiskas atšķirības, izvērtējot situāciju katrā slimnīcā atsevišķi. Visā starpkaru periodā nemainīgi lielākās problēmas bija Rīgas psihiatriskajās slimnīcās. Ja reǵionos virs normas uzņemto pacientu skaits vidēji nepārsniedza pāris procentu, tad Sarkankalna slimnīcā tas pārsniedza 21\% (1935. gadā), bet Aleksandra Augstumu iestādē - pat $44 \%$ (1938. gadā). ${ }^{72}$

67 Sočņeva Z., Liepin̦š J. No Aleksandara Augstumu slimnīcas vēstures / Acta medico-historica Rigensia. - Vol. III (XXII). - 1997. - 101. lpp.

68 Tautas veselības statistika 1938. - Rīga: Valsts statistiskā pārvalde, 1940. - 73. lpp.

69 Latvijas Republikas III Saeimas IV sesijas 10. sēde 1929. gada 22. novembrī. Latvijas Republikas III Saeimas stenogrammas. Ārkārtējā un IV sesija. 1929. gads. - Rīga: Latvijas Republikas Saeimas izdevums, 1929. - 505. sl.

70 Tautas veselības statistika 1929. - Rīga: Valsts statistiskā pārvalde, 1930. - 32. lpp.

71 Tautas veselības statistika 1938. - Rīga: Valsts statistiskā pārvalde, 1940. - 72.-73. lpp.

72 Tautas veselības statistika 1935. - Rīga: Valsts statistiskā pārvalde, 1936. 76.-77. lpp.; Tautas veselības statistika 1938. - Rīga: Valsts statistiskā pārvalde, 1940. - 72.-73. lpp. 
Psihiatrs Hermanis Buduls (1882-1954) atzīmēja, ka Latvijas psihiatriskajās slimnīcās bezgultnieki bijuši arī pirms Pirmā pasaules kara. Tomēr pirmskara periodā tas bija pārejošs stāvoklis, bet pēckara gados kḷuva par stabilu parādību. Bezgultnieki naktis pavadīja improvizētās gul̦vietās - uz rāmja, sola u. tml., ko dienā vai nu aizvāca prom, vai lietoja citām vajadzībām. Atzīstot bezgultniekus par negatīvu parādību, H. Buduls tomēr ar gandarījumu atzīmēja, ka Sarkankalna slimnīca vietu trūkuma dēḷ nav noraidījusi nevienu garīgi slimu Rīgas pilsoni, kam slimnīcā ir bijusi nepieciešama ārstēšana. ${ }^{73}$

Kaut arī lauku slimnīcās situācija ar bezgultniekiem nebija tik izteikta kā Rīgā, arī tur saskārās ar piemērotu telpu trūkumu. 1929. gadā Madonas apriņķa valdes priekšsēdētājs apmeklēja Strenču slimnīcu, lai pārliecinātos, vai tiešām nav iespējams tur uzņemt Madonas apriņķa iedzīvotājus, kas gaida rindā, kad atbrīvosies vieta slimnīcā. Viņš secināja, ka tik tiešām jaunu slimnieku uzṇemšanu Strenču slimnīcā traucē nevis iestādes vadītāju nevēlēšanās to darīt, bet gan reāls telpu trūkums, nav kur šos slimniekus izvietot:

"Vājprātīgo lielā skaita dēḷ slimnīca ir pārpildīta un telpu trūkuma dēl jau vairāki slimnieki guḷ uz grīdas, uz kop̄ọa maisa... Arī dienās slimnieki uzturas gul̦amās telpās, jo atsevišķu dienas telpu slimnīcā nav. Pat stipri nemierīgie salikti vairāki vienā telpā, kas normālos apstākḷos pavisam nebūtu pielaižams, tomēr ja 42 stipri nemierīgiem paredzētās telpās jāsaliek 80 slimnieki, tad arī sargu stāvoklis ir stipri grūts, jo lielākā skaitā kopā esot vājprātīgie vairāk uzbudināti, un nemiers viṇu telpās esot bez pārtraukuma arī naktī, guḷamā laikā.,"’4

Psihiatrs K. Neibergs, vērtējot situāciju Ģintermuižas slimnīcā, arī aprakstīja līdzīgas problēmas. Viņš uzsvēra, ka normāli guḷamajās palātās uz vienu slimnieku vajadzētu būt vismaz 20 kubikmetriem gaisa, bet Ģintermuižas slimnīcā 1938. gadā uz vienu pacientu bija vidēji tikai 12 kubikmetru gaisa. Viņš atgādināja, ka "nav arī jāaizmirst, ka ne visi

73 Buduls H. Latvijas galvas pilsētas Rīgas Sarkankalna slimnīcas vēsture 1862.-1937. - Rīga: Pilsētas valdes izdevums, 1938. - 187. lpp.

74 Mūrnieks A. Mani novērojumi Strenču ārprātīgo slimnīcā // Iekšlietu Ministrijas Vēstnesis, 1929. g. 10. sept.; 331: 2. lpp. 
vājprātīgie ir muļksi, kas nekā nesaprot. Daudzreiz mums nākas dzirdēt vājprātīgus ar sašutumu runājam par neiespējamo gaisu". ${ }^{75}$ Turklāt lielais slimnieku skaits, kas bija izvietots pārāk mazajās telpās, traucēja radīt "veselīgu psīchisko atmosfairu”. Psihiatrs uzsvēra, ka jauno pacientu daudz vairāk nekā medicīniskais personāls spēj ietekmēt vispārējā noskaņa nodaḷā un tas ātri piemērojas nodaḷas garam - "ja labs, tad labam, ja ḷauns, tad lıunam".76 1938. gadā K. Neibergs, atskatoties uz situāciju psihiatriskajā aprūpē, kur par spīti pieliktajām pūlēm pacientiem aizvien trūka veselību veicinošu, labvēlīgu sadzīves apstākḷu, teica pavisam skarbus vārdus: "Mūsu slimnīcās ir ārkārtīgi daudz tādu, kam slimnīca nesusi vairāk ḷauna nekā laba, izņemot to, ka slimnieki te ir izolēti no sabiedrības, kuru viṇi ārpusē traucē." 77

Kas attiecās uz medicīniskā personāla skaitu slimnīcās, to regulēja jau 1920. gadā pieņemtie valdības noteikumi. ${ }^{78}$ Tie paredzēja, ka psihiatriskajās nodaḷās, kur ir vairāk par 40 gultām, jābūt direktoram, bet uz katrām 80 gultām - vienam ārstam, uz katrām 60 gultām - vienai vecākajai un divām jaunākajām māsām. Kopēju skaits variēja atkarībā no tā, vai tā bija mierīgo vai nemierīgo pacientu nodaļa - attiecīgi viens kopējs četriem vai viens trijiem slimniekiem.

Patiesībā psihiatriskajās slimnīcās ne vienmēr šie noteikumi tika ievēroti. Var saprast H. Budula aso reakciju uz 1939. gada oktobra numurā laikrakstā "Rīts"79 publicēto rakstu, kurā tika aprakstīti Veselības departamenta izstrādātie, taču vēl neapstiprinātie noteikumi ārstniecības iestādēm. Tie paredzēja, ka turpmāk uz katrām 25 gultām bez slimnīcas vadītāja jābūt vēl vienam ārstam, vienai žēlsirdīgai māsai un pieciem mācītiem kopējiem. H. Buduls nekavējoties Veselības departamentam nosūtīja paziņojumu, kurā secināja, ka, ņemot vērā Sarkankalna slimnīcā stacionēto pacientu skaitu (ap 890), slimnīcā būtu nepieciešami 36 ārsti, 36 žēlsirdīgās

75 Neubergs K. Psīchiatriskās slimnīcas, to darbība, uzdevumi un viedokḷi: Rakstu sakopojums Ģintermuižas slimnīcas (dib. 1887. gada 3. jūnijā) 50 gadu darbības atcerei. - Jelgava: Tautas Labklājības ministrijas Veselības departamenta Ģintermuižas slimnīca, 1938. - 20. lpp.

76 Turpat, 21. lpp.

77 Turpat.

${ }^{78}$ LVVA, 4578. f., 4. apr., 208. 1., 58. 1p.

79 Uzlabos ārstniecības apstākḷus slimnīcās // Rīts, 1939. g. 7. okt.; 277: 2. lpp. 
māsas un 180 slimnieku kopēji - kas, ņemot vērā personāla skaitu slimnīcā visu starpkaru periodu, izskatījās pavisam neiespējami, zinot, ka visās psihiatriskajās slimnīcās kopā 20. gs. 30. gadu pirmajā pusē bija maksimāli 36 ārsti. ${ }^{80}$ Likums tomēr tika pieņemts 1939. gada 20. oktobrī, gan ar nelielām izmaiñām - ārstu, māsu un piecus slimnieku kopējus paredzot uz katriem 30 pacientiem. Arī šñ prasība tomēr bija nereāla un praksē tā arī netika īstenota.

\section{Garīgi slimo cilvēku stacionēšanas problēmas}

Teorētiski psihiatrisko pacientu ievietošana slimnīcās Latvijā bija loti vienkārša. Izveidojoties Latvijas valstij, psihiatrisko pacientu stacionēšanu turpināja regulēt vecie Krievijas civillikumi un jaunizstrādātie valdības noteikumi, kas paredzēja, ka slimnieka ievietošanai psihiatriskajā slimnīcā nepieciešama tikai viena ārsta "apliecība” jeb nosūtījums. Turklāt šim ārstam nevajadzēja būt psihiatram. Bija nepieciešama personas apliecība, samaksa par 90 gultas dienām uz priekšu vai, ja persona maksātnespējīga, apliecība no attiecīgas pašvaldības iestādes, ka šñ iestāde uzņemas maksāt par slimā ārstēšanu un kopšanu. ${ }^{81}$ Par jau notikušu stacionēšanu nebija prasības ziņot tiesu instancēm, slimniekus vajadzēja tikai pieregistrēt vietējā policijā. Salīdzinot ar citām Eiropas valstīm, Latvijā šì sistēma bija daudz vienkāršāka, jo, piemēram, Vācijā likums noteica, ka psihiatrisko pacientu stacionēšanai nepieciešams trīs ārstu konsilijs, kurā vismaz viens ārsts ir psihiatrs. Gādība par pacienta īpašumu aizsargāšanu teorētiski tika uzdota bāriṇtiesām, bet tālākā pacienta uzturēšanās slimnīcā bija atkarīga tikai no ārstējošā ārsta. ${ }^{82}$ Šādu vienkāršotu pacientu

80 Aprēķināts no: Tautas veselības statistika 1932. un 1933. - Rīga: Valsts statistiskā pārvalde, 1935. - 52.-53. lpp.; Tautas veselības statistika 1934. - Rīga: Valsts statistiskā pārvalde, 1936. - 70.-71. lpp.; Tautas veselības statistika 1935. - Rīga: Valsts statistiskā pārvalde, 1936. - 76.-77. lpp.; Tautas veselības statistika 1936. Rīga: Valsts statistiskā pārvalde, 1937. - 82.-83. lpp.

${ }^{81}$ LVVA, 4578. f., 4. apr., 208. 1., 55. lp.

82 Hibšmans V. Garā saslimušo tiesību aizsargāšana // Latvijas Ārstu Žurnāls, 1929; 7/8: 597.-598. lpp.; Hibšmans V. Gara vājības konstatěšana lauku ārstu ambulances apstākḷıs // Latvijas Ārstu Žurnāls, 1926; 9/10: 332. lpp.; Valdības rīkojumi un pavēles // Valdības Vēstnesis, 1939. g. 19. jūn.; 135: 4. lpp. 
stacionēšanas sistēmu psihiatri uzskatīja par ieguvumu. Līdzīga sistēma saglabājās arī pēc 1939. gada tiesību aktu grozījumiem. Tie noteica, ka slimos uzņem iestādes direktors, raugoties pēc brīvo vietu skaita; vēl bija nepieciešams iesniegt ārsta apliecību par slimību, personas apliecību un vājprātīgo nodal̦ās iemaksāt uz priekšu ārstēšanās maksu par 90 dienām. Maksātnespējīgām personām - ziņas par slimnieka un viņa piederīgo mantas stāvokli no policijas vai pašvaldības iestādes, pie kuras slimnieks pieder. ${ }^{83}$

Lai gan tika atvieglota pacientu uzņemšanas sistēma, rindas uz vietu psihiatriskajā stacionārā bija milz̄̄gas jau iepriekš aprakstītās slimnīcu pārmērīgas noslodzes dēḷ. N̦emot vērā situāciju, jaunu, akūti saslimušo pacientu uzņemšana bieži bija apgrūtināta. Parasti neatteica tikai slimniekiem, "kuri apdraud citus pilsoņus", ${ }^{84}$ bet pārējiem uz stacionēšanu nācās gaidīt garās rindās. ${ }^{85}$

Realitātē slimnieka ievietošana slimnīcā, pat maksātspējīga pacienta, varēja izrādīties gara un birokrātiska. Tas redzams arī no Tautas labklājības ministrijas sarakstes materiāliem Latvijas Valsts vēstures arhīvā (LVVA), piemēram, no sarakstes kāda garīgi slimā Friča J. stacionēšanas lietā. 1939. gada 25. novembrī pacienta māsa Anna J. rakstīja Tautas labklājības ministrijai, ka "beidzamā laikā Fricis J. man katru dienu uzbrūk un apdraud dzīvību", lūdzot viņu ievietot kādā no psihiatriskajām slimnīcām "uz mantojuma rēksina dal̦as”. Gandrīz mēnesi vēlāk, 1939. gada 22. decembrī, Veselības departaments uzdeva Valkas apriņķa ārstam apskatīt šo pacientu un uzrakstīt atsauksmi par nepieciešamību viṇu ievietot slimnīcā. 1940. gada 11. janvārī Veselības departamentam ārsts rakstiski paziņoja, ka apskatītais vīrietis sirgst ar šizofrēniju, kas izpaužas garīgā trulumā un apātijā pret pasauli. Sirdzējs klejojot, svešus cilvēkus neaiztiekot, māsai dažreiz uzbrūkot. Tikai ar citu personu palīdzību,

83 Likumdošana // Tautas Labklājīîas Ministrijas Mēnešraksts, 1939; 6: 559. lpp.

${ }^{84}$ Sarkankalna psichiatriskā slimnīca stipri pārpildīta // Latvijas Kareivis, 1932. g. 17. jūl.; 157: 4. lpp.

${ }^{85}$ Latvijas Republikas III Saeimas III sesijas 25. sēde 1929. gada 15. maijā. Latvijas Republikas III Saeimas stenogrammas. III sesija. 1929. gads. - Rīga: Latvijas Republikas Saeimas izdevums, 1929. - 859.-860. sl.; Alks O. Lipīgas slimības mazinājušās // Rīts, 1936. g. 2. janv.; 2: 4. lpp.; Vājprātīgo slimnieku skaits pieaug // Latvijas Kareivis, 1931. g. 13. jūn.; 129: 4. lpp. 
lietojot spēku, iespējams viņu pārg̣ērbt un nomazgāt. Lielās netīrības dēl slimniekam grūti atrast kopējus vai ievietot kādā patversmē. Valkas apriņķa ārsts uzskata, ka pacientu būtu iespējams ievietot psihiatriskajā slimnīcā. 24. janvārī, divus mēnešus pēc pirmreizējā lūguma saņemšanas, Veselības departaments nosūtīja vēstuli gan slimnieka māsai, gan Valkas pilsētas valdei, māsai paziņojot, ka "šai lietā Jums jāgriežas pie pilsētas pašvaldības", bet pilsētas valdei, ka "nosūta Jūsu ieskatam apriņķ̧a ārsta norakstu vājprātīgā Friča J. lietā”’ ${ }^{86}$

Līdzīga, birokrātisko situāciju raksturojoša sarakste atrodama arī kādas Jūrmalas pilsētas iedzīvotājas Almas V. lietā. 1940. gada 15. janvārī Jūrmalas pilsētas vecākais griezās pie Veselības departamenta ar lūgumu pacienti ievietot kādā no psihiatriskajām slimnīcām, apgalvojot, ka jau pagājušā gada decembrī esot griezies pie Aleksandra Augstumu slimnīcas, Strenču un Ģintermuižas psihiatriskajām slimnīcām, bet uz šo lūgumu Strenču psihiatriskā slimnīca esot atbildējusi, ka paciente ievietojama Jelgavas vai Aleksandra Augstumu slimnīcā, Ģintermuižas slimnīca esot savukārt paskaidrojusi, ka tā uzņemot slimniekus no Zemgales un Kurzemes, bet Aleksandra Augstumu slimnīca esot paskaidrojusi, ka tā pacienti nevarot uzņemt vietu trūkuma dēḷ. Pēc sarakstes ar minēto slimnīcu vadītājiem Veselības departaments 3. februārī atbildēja Jūrmalas pilsētai, ka "valsts psihiatriskās slimnīcas pirmā kārtā uzņem tādus slimniekus, kuriem ārstēšana ir nepieciešama .. Kronisko slimnieku uzņemšana slimnīcās ir ierobežota, jo visas psihiatriskās slimnīcas ir pārpildītas, kādēḷ šādi slimnieki pieteicami kā kandidāti uz brīvām vietām."87

Vēl spilgtāki apraksti atrodami periodikā, kur var izsekot arī akūto pacientu garajam ceḷam no slimības pazīmju pirmreizējas konstatēšanas līdz nonākšanai psihiatriskās aprūpes vietā. Te spilgti atspoguḷojas būtiskā atšksirība starp teorētisko un ļoti vienkāršo stacionēšanas mehānismu un reālo situāciju. Visbiežāk visnotaḷ garajā psihiski slimā stacionēšanas procesā pacients sākotnēji pabija policijas iecirkn̄̄, tad pagasta valdes mājā un tikai tad, iespējams, tika nogādāts ārstēšanai psihiatriskajā slimnīcā. Viens gadījums, kurā loti labi var izsekot pacienta garajam ceḷam uz psihiatrisko slimnīcu, aprakstīts laikrakstā "Brīvā

\footnotetext{
${ }^{86}$ LVVA, 4578. f., 4. apr., 683. 1., 1.-7. lp.

87 Turpat, 13.-18. lp.
} 
Zeme" 1937. gadā. ${ }^{88}$ Tajā stāstīts par kādu sievieti, kas "pēkšņi saslimusi” Rīgas-Jaunlatgales pasažieru vilcienā. Sieviete nogādāta Kārsavas policijas iecirknī, kur “izrādījusi vājprāta pazīmes”. Pēc sievietes personības noskaidrošanas policija viṇu nogādājusi Šksilbēnu pagasta valdē. Pagasta valde tālāk sievieti nodevusi viņas māsasvīra aprūpē. Pēc dažām dienām māsasvīrs atvedis pacienti atpakaḷ uz pagasta valdi, sakot, ka tā traucējot mājas mieru. Sieviete līdz jauna "saimnieka-uzraudzītāja" atrašanai atstāta pagasta valdē, no kurienes aizbēgusi pie brāļa, kur pastrādājusi smagu noziegumu - nogalinājusi 10 mēnešus veco brāḷa bērnu. Tad to atkal sagūstījusi policija un beidzot nogādājusi Daugavpils psihiatriskajā slimnīcā.

Šo un līdzīgu gadījumu apraksti periodiskajos izdevumos un arhīva dokumentos liecina par šādu realitāti: ja pacienta tuvinieki no psihiski slimā aprūpes atteicās, tā kḷuva, galvenokārt, par pašvaldības problēmu. Šādu kārtību arī oficiāli apstiprināja Veselības departaments 1933. gada septembrī, izsūtot apkārtrakstu, kas noteica, ka par garīgi slimajiem, kurus brīvo vietu trūkuma dēl nevar uzṇemt ārstēšanai slimnīcās, jārūpējas viņu piederīgajiem; ja tie ir trūcīgi un nespēj slimnieku uzturēt - tad attiecīgai pašvaldības iestādei. ${ }^{89}$ Pašvaldībām bija jāmeklē risinājumi, kā aprūpē nodot pacientu un kur viņu novietot līdz brīdim, kad aprūpētāju atradīs. Lielākai daļai pašvaldību nebija telpu, kas derētu kaut īslaicīgai psihiatrisko slimnieku izvietošanai. Pašvaldības turēja viņus gan apcietinājumā, gan centās ierīkot speciālas telpas kādā no pagastam piederošām ēkām, dažas - norīkoja apsardzi, līdz radīsies iespēja pacientu uzṇemt slimnīcā..$^{90}$ Ar tādu pašu problēmu saskārās arī apriņķa valdes, kuru teritorijā atradās psihiatriskās slimnīcas. Gadījumā, ja pagasta darbinieki pacientu bija aizveduši uz slimnīcu, bet izrādījās, ka brīvu vietu tur nav, viņu centās atstāt apriṇķa priekšnieka uzraudzībā.

88 Drausmīgs noziegums vājprāta lēkmē // Brīvā Zeme, 1937. g. 27. sept.; 218: 2. lpp.

89 LVVA, 2917. f., 1. apr., 4. 1., 159. 1p.

90 Saeimas komisijās // Latvijas Kareivis, 1928. g. 3. feb.; 27: 1. 1pp.; Latvijas Republikas III Saeimas IV sesijas 10. sēde 1929. gada 22. novembrī. Latvijas Republikas III Saeimas stenogrammas. Ārkārtējā un IV sesija. 1929. gads. - Rīga: Latvijas Republikas Saeimas izdevums, 1929. - 506. sl.; Pēkšņi kḷuvis vājprātīgs // Brīvā Zeme, 1936. g. 24. nov.; 267: 6. lpp.; Vājprātīgo posts // Iekšlietu Ministrijas Vēstnesis, 1928. g. 13. jūl., 218: 2. lpp. 
1928. gadā “Iekšlietu Ministrijas Vēstnes’̄” tika aprakstīta nepatīkama situācija:

“Tā Jaunlatgales apr. valde nosūtījusi uz Daugavpili vājprātīgo, kuru nevarēja slimnīcā uzņemt un vājprātīgā pavadoṇi nogādāja slimo Daugavpils apriņ̧̧a priekšnieka kancelejā "novietošanai” uz dažām dienām, bet tā kā turpat atrodas prefektūra ar arestu telpām, apr. priekšnieks, pie kura kancelejas nav nekādu telpu vājprātīgā uzturēšanai, slimnieku nav pieñēmis. Tomēr dažas dienas vēlāk no L,audonas pag. valdes tajā pat apr. priekšn. kancelejā ieveda citu vājprātīgo un atkal "novietošanai uz pāris dienām”, kāpēc apr. priekšnieks lūdza administratīvā departamenta gādību, lai pašvaldības turpmāk nepārvērstu viņa kanceleju par Latvijas vājprātīgo etapa punktu, vēl vairāk tāpēc, ka vājprātīgie kancelejā trokšņo un traucē ierēdņus darbā." ${ }^{1}$

Turklāt pagastu valdēm bez iepriekšējas sazināšanās ar slimnīcām (vai Tautas labklājības ministriju, no 1928. gada) par stacionēšanas iespējām bija aizliegts pacientus sūtīt uz psihiatriskām slimnīcām. ${ }^{92}$ Šāds valdības rīkojums tika izdots jau 1922. gadā, atsaucoties uz valsts slimnīcu sūdzībām, ka pašvaldības, citas iestādes un arī privātpersonas sūta uz valsts slimnīcām ārstēšanai slimniekus, iepriekš neprasot attiecīgas slimnīcas administrācijai, vai ir brīvas vietas, neuzrādot diagnozi un slimnieka maksātspēju. Tā kā slimnīcās brīvu vietu nebija, atbilde bieži bija vienkārša: "Mums nav telpu, kur likt šos vājprātīgos." 93 Tāpēc cilvēks, kas pagasta uzdevumā bija atvedis uz slimnīcu psihiski slimo pacientu, bija spiests braukt atpakaļ uz pagastu un nodot slimnieku pagasta valdes rīcībā.

"Ko lai pagasta valde ar viņu iesāk? Viņa to palaiž brīvībā, lai viņš dzīvo pie saviem piederīgiem, vai arī bez kaut kādas uzraudzības vai apgādības," apgalvoja kāds sociāldemokrātu pārstāvis Saeimas sēdē 1929. $\operatorname{gad} \bar{a} .{ }^{94}$

91 Vājprātīgo posts // Iekšlietu Ministrijas Vēstnesis, 1928. g. 13. jūl., 218: 2. lpp.

92 Valdības iestāžu paziņojumi // Valdības Vēstnesis, 1922. g. 27. apr., 93: 2. lpp.; Tautas labklājības ministrijas paskaidrojumi pie likuma par sociālo apgādību izvešanas dzīvē // Valdības Vēstnesis, 1928. g. 27. apr.; 94: 4. lpp.

${ }^{93}$ Latvijas Republikas III Saeimas IV sesijas 10. sēde 1929. gada 22. novembrī. Latvijas Republikas III Saeimas stenogrammas. Ārkārtējā un IV sesija. 1929. gads. - Rīga: Latvijas Republikas Saeimas izdevums, 1929. - 506. sl.

94 Turpat. 
Īpaši nelabvēlīga situācija bija izveidojusies laukos. 1929. gadā Saeimā tika atstāstīts kāds gadījums, ka valsts muižā "kḷuva vājprātīgs" kāds muižas darbinieks. Lai gan muižas pārvalde griezās pie visām Latvijas psihiatriskajām slimnīcām, sasirgušo neizdevās stacionēt - visās iestādēs atbildēja, ka nav nevienas vakantas vietas. Savukārt Valmieras apriņ̧̧a valdes priekšsēdētājs, pie kura, nevarēdams atrast vietu slimniekam, griezās muižas pārvaldnieks, atbildēja pavisam stingri - vinšs piedraudēja muižas pārvaldniekam ar sešu mēnešu cietumsodu, ja viņš slimo sūtišot uz Strenčiem bez aţ̦aujas.

Aprakstīti arī gadījumi, ka vājprātīgie aizvesti uz Tautas labklājīibas ministriju un atvedēji vienkārši pateikuši: "Vai nu jūs ņemiet šos vājprātāgos pretim, vai mēs viņus palaidīsim uz ielas, lai iet, kur grib, jo uz laukiem nav nekāda glābiņa." ${ }^{95}$ Līdzīgi 1933. gadā situāciju raksturoja Saeimas deputāts sociāldemokrāts Andrejs Veckalns (1879-1942): "Vājprātīgie cilvēki tiek atvesti pilsētā un atstāti uz ielas; paši piederīgie aizmūk prom, lai tādā kārtā iedabūtu kādu bīstami vājprātīgo slimnīcā.".96

Šāda valsts un pašvaldību iestāžu nesaprašanās sociālās aprūpes jautājumos nespēja uzlabot situāciju psihiatrijā: slimnīcas bija pārpildītas ar hroniski slimiem pacientiem, kam bija nepieciešama tikai aprūpe, bet tie slimnieki, kam bija iespējama ārstēšana, bieži atradās ārpus slimnīcu sienām. Situācijas absurdu labi apzinājās arī psihiatri. Arnolds Laksbergs to raksturoja ar šādiem vārdiem:

"Pilsoṇiem nevajadzētu ilgi un nesekmīgi klauvēt pie psihiatrisko slimnīcu durvīm, šie vārti būtu katrā laikā atverami bez liekas klauvēšanas kā tiem, kam slimnīcā nepieciešami jāiestājas, kā tiem, kam lietderīgi no viņas izrakstīties."97

${ }^{95}$ Latvijas Republikas III Saeimas IV sesijas 10. sēde 1929. gada 22. novembrī. Latvijas Republikas III Saeimas stenogrammas. Ārkārtējā un IV sesija. 1929. gads. - Rīga: Latvijas Republikas Saeimas izdevums, 1929. - 508. sl.

96 Latvijas Republikas IV Saeimas VI sesijas 28. sēde 1933. gada 4. jūlijā. Latvijas Republikas IV Saeimas stenogrammas. VI sesija. 1933. gads. - Rịga: Latvijas Republikas Saeimas izdevums, 1933, 1177. sl.

${ }_{97}$ Laksbergs A. Rūpes par garīgi slimiem. Kāpēc pārpildītas psichiatriskās slimnīcas (Beigas) // Latgales Vēstnesis, 1938. g. 30. mar.; 35: 2. lpp. 


\section{Sociālās apgādības likums}

1928. gadā stājās spēkā Sociālās apgādības likums. ${ }^{98}$ Tas paredzēja valsts un pašvaldību pienākumu sociāli apgādāt trūcīgos valsts iedzīvotājus, nespējniekus, bāreņus, defektīvus bērnus, ar bīstamām lipīgajām slimībām (tuberkulozi, mēri, lepru, trakumsērgu, sifilisu u. c.) sasirgušos un arī garīgi saslimušos, kam nepieciešama ārstēšana "speciālās iestādēs". Likums paredzēja, ka par "vājprātīgo, kas ievietots speciālā valsts iestādē" un uzskatāms par sociāli apgādājamu var ņemt no pašvaldības par labu valstij uztura naudu ne vairāk par vienu trešdaļu no iestādes faktiskajiem izdevumiem šā slimnieka uzturēšanā. Ja pacients nepiederēja sociāli apgādājamo kategorijai, uztura naudu no vienas trešdaļas līdz pilnam apmēram likums paredzēja piedzīt no pacienta tuviniekiem vai paša īpašumiem. Uztura nauda nebija ņemama par vājprātīgiem un garīgi vai morāliski defektīviem bērniem, ja tie iestādē turami pēc tiesas sprieduma. Faktiski šis likums paredzēja, ka pašvaldības finansē $1 / 3$ no psihiatrisko pacientu ārstēšanas izdevumiem. Turklāt likumā bija iestrādāts arī punkts, ka šo pienākumu izpildīšana no valsts puses - "uzturēt zīdaiņus līdz divu gadu vecumam", "uzturēt vājprātīgos speciālās iestādēs", "ārstēt, kopt un uzturēt trūcīgas personas, kas saslimušas ar tuberkulozi lip̄igā stadijā”, un "ambulatoriski ārstēt veneriski saslimušos" - ir "izvedama pakāpeniski, atkarībā no valsts līdzekḷiem”. Jaunā Sociālās apgādības likuma paskaidrojumi konkretizēja, ka pacientu nosūtīšanu uz stacionāru regulē vecie, 1922. gadā pieņemtie, noteikumi - "par vājprātīgo uzņemšanu valsts slimnīcās, vietu trūkuma dēḷ, katrā atsevišķā gadījumā jāsazinās ar Tautas labklājības ministrijas Veselības departamentu vai attiecīgo valsts slimnīcu".99

Tas, ka garīgi slimo aprūpe vietu trūkuma slimnīcās dēl bija grūti pieejama un ka par ārstētiem pacientiem valsts varēja piedzịt naudu no pagastu un apriņķu valdēm, raisīja aizvien lielāku pašvaldību neapmierinātību. 1929. gada nogalē apriņķu valžu pārstāvju apspriedē tika caurskatītas aktuālākās pašvaldību problēmas, arī “ārstniecības jautājums”. Ārstniecības jautājumā pieņēma piecus atzinumus, no kuriem četri skāra tieši psihiatrisko

98 Likums par sociālo apgādību // Valdības Vēstnesis, 1928. g. 13. apr.; 82: 1.-2. lpp.

99 Tautas labklājības ministrijas paskaidrojumi pie likuma par sociālo apgādību izvešanas dzīvē // Valdības Vēstnesis, 1928. g. 27. apr.; 94: 4. lpp. 
aprūpi. Tas lıauj secināt, ka tieši psihiatriskajā aprūpē bija samilzušas vislielākās problēmas. Apspriedē pieņemtie atzinumi bija:

"Vājprātīgo slimnieku uzturēšana un ārstēšana jāuzṇemas valstij; lūgt valdību paplašināt vājprātīgo slimnīcas; Popes muižāa ierīkot vājprātīgiem koloniju; lūgt Tautas labklājības ministriju nākošā gada budžetā paredzēt plašus līdzekḷus vājprātīgo slimnīcu izbūvēm, ņemot vajadzīgos līdzekḷus no valsts piemaksām slimo kasēm; vājprātīgu ārstēšana pašvaldību slimnīcās ir dārgāka nekā valsts slimnīcās un šo starpību lūgt segt no valsts līdzekḷiem.”'100

Valsts savukārt pašvaldībām pārmeta par "apārstēto" un mierīgo pacientu neizņemšanu no slimnīcām pietiekami ātri:

"Tā Veselības departaments paziņojis pašvaldības departamentam, ka Strenču vājprātīgo slimnīcā izvesel̦ojušies 20 slimnieki, kas mierīgi varētu dzīvot mājas apstākḷlos, bet kurus pašvaldības par spīti vairākkārtējiem uzaicinājumiem atsakās izṇemt un veltīgi maksā naudu par to uzturēšanu."

Pašvaldības argumentēja savu rīcību ar to, ka lielākai daḷai nav piemērotu telpu slimnieku izvietošanai, ka radinieki nevēlas ņemt savus slimniekus pie sevis pat par atlīdzību un ka slimnieku uzturēšana pagastā pašvaldībai izmaksā dārgāk nekā pacientu uzturēšana slimnīcā. ${ }^{101}$

Lai mazinātu pašvaldību neapmierinātību, 1935. gadā tika pieņemti Sociālās apgādības likuma grozījumi, kas paredzēja, ka turpmāk valsts uzṇemas pilnā apmērā (nevis kā iepriekš - ar pašvaldību līdzdalību) "uzturēt speciālās iestādēs vājprātīgos, kas saskaņā ar šì likuma noteikumiem pieder pie lauku pašvaldībām". ${ }^{102}$ Pēc pāris mēnešiem "Valdības Vēstnesī” tika publicēts rīkojums visiem apriņķu lauku pašvaldību vecākajiem. Tas skaidroja pieņemto grozījumu būtību. ${ }^{103}$ Tautas labklājības

100 Apriņķu valžu pārstāvju 1929. gada 11. oktobra apspriedē pieņemtie atzinumi // Iekšlietu Ministrijas Vēstnesis, 1929. g. 18. okt.; 342: 2. lpp.

101 Vājprātīgo posts // Iekšlietu Ministrijas Vēstnesis, 1928. g. 13. jūl.; 218: 2. lpp. 102 Pārgrozījumi likumā par sociālo apgādību // Valdības Vēstnesis, 1935. g. 17. apr.; 90: 2. 1pp.

103 Valdības rīkojumi un pavēles. Visiem apriņ̧̧̧u lauku pašvaldību vecākajiem // Valdības Vēstnesis, 1935. g. 3. jūl., 146: 1. lpp. 
ministrijā pēc grozījumu pieņemšanas lielā skaitā bija ienākuši pieprasījumi no pagastu pašvaldībām, kas pieprasīja atmaksāt pagastu nespējnieku uzturēšanu, tostarp to, kas sociāli apgādājamo kārtā bija nonākuši plānprātības dēḷ. Rīkojumā tika uzsvērts, ka pieņemtie grozījumi paredz vājprātīgo uzturēšanu uz valsts rēksina vienīgi speciālās iestādēs, par kādām uzskatāmas valsts un pašvaldību psihiatriskās slimnīcas, "kurās neuzņem visas personas, kas prātā aprobežotas, bet tikai tādus vājprātīgos, kam, pēc ārsta atsauksmes, tiešām nepieciešama ārstēšanās psihiatriskā slimnīcā’. Tepat arī atzîts, ka psihiatriskās slimnīcas nereti ir pārpildītas, tāpēc pacientu uzņemšana notiks pakāpeniski, iepriekš sazinoties ar attiecīgo slimnīcu vai Veselības departamentu. Vien̄̄gais reālais labums lauku pašvaldībām no šiem grozījumiem bija tas, ka tie atcēla pirms tam esošo kārtību par līdzmaksājumu līdz 1/3 no faktisko izdevumu apmēriem par sociāli apgādājamiem garīgi slimajiem, kas ārstējās psihiatriskajās slimnīcās. Par slimniekiem, kas atradās radinieku aprūpē vai nespējnieku patversmēs, joprojām bija jārūpējas pašvaldībām. Savukārt pilsētu pašvaldībām gan aizvien saglabājās iebildumi, ka likums noteica valsts pilna apmēra iesaisti tikai lauku pašvaldību apgādājamiem. Tās uzskatīja, ka arī pilsētu pašvaldību trūcīgo kurlmēmo, neredzīgo un vājprātīgo apgādes izdevumi būtu jāsedz valstij pilnā apmērā. ${ }^{104}$

Savukārt 1939. gadā pieņemtie grozījumi ${ }^{105}$ atkal paredzēja pašvaldību finansiālu līdzdalību trūcīgu vājprātīgo ārstēšanā ne vairāk kā 1⁄3 apmērā no faktiskajiem ārstēšanas izdevumiem vai no publicētās ārstēšanas maksas. Šie grozījumi paredzēja iespēju ārstēšanas maksu, ko piedzen no piederīgiem vai pacienta īpašumiem, samazināt līdz pat 1/10 no faktiskajiem izdevumiem.

\section{Deinstitucionalizācijas mēǵginājumi}

Viens no psihiatriskās aprūpes sistēmas mazspējas risinājumiem bija mērķtiecīga slimnīcu atbrīvošana no mierīgiem hroniskajiem pacientiem, kam nebija nepieciešama speciāla ārstēšana. Mierīgo pacientu nodošanu t. s. mājas aprūpē Latvijas teritorijā praktizēja jau kopš 19. gs. beigām. Ģimenēm, kas uzņēmās šo slimnieku kopšanu, izmaksāja nelielu

104 Pilsētu savienības darbība // Pašvaldības Balss, 1939. g. 1. jūl.; 7: 491. lpp.

105 Pārgrozījumi un papildinājumi likumā par sabiedrisko apgādību // Valdības Vēstnesis, 1939; 151: 1. lpp. 
pabalstu 60-180 rubļu apmērā. Slimnieku dzīves apstākḷus un veselību uzraudzīja ārsts. ${ }^{106}$ Šo praksi centās atjaunot arī starpkaru periodā. 1936. gadā Veselības departaments slimnīcu pārpild̄̄̌sanas jautājuma risināšanai sasauca visu valsts psihiatrisko slimnīcu vadītāju sanāksmi, kurā tika nolemts atjaunot slimnieku izdošanu ǵimenes kopšanā. ${ }^{107}$ Tika izstrādāti speciāli noteikumi, kā aprūpējams un uzraugāms šāds slimnieks. ${ }^{108}$ Attīdzība par slimnieka kopšanu variēja no 16 līdz 30 latiem mēnesī. ${ }^{109}$ Visās lielākajās slimnīcās - citā veiksmīgāk, citā mazāk veiksmīgi - slimnieku izdošana mājas aprūpē tika ieviesta. Taču bieži pacientu radinieki, īpaši lielajās pilsētās, no šādas prakses atturējās. "Nesamērīgi lielākais vairums mazturīgo Rīgas pilsoņu atrod par izdevīgāku atstāt savus slimniekus iestādē uz pilsētas rēķina nekā tos turēt un kopt pie sevis mājā par 30 latiem mēnes̄̄," atzina H. Buduls. ${ }^{110}$ 1936. gadā no Sarkankalna slimnīcas mājas aprūpē bija izdoti tikai ap 10 pacientu. ${ }^{11}$

Kaut pilsētā šñ iniciatīva palika bez lielākas ievērības, laukos atsaucība tai pakāpeniski pieauga, īpaši Latgalē, kaut arī tur atlīdzība par slimnieka uzturēšanu bija pat mazāka - no 16 līdz 25 latiem mēnesī. ${ }^{112}$ Pirmais pacients no Daugavpils slimnīcas tika nodots ğimenes kopšanā par atlīdzību 1936. gada 1. jūlijā. Līdz gada beigām tādu bija jau 25. No visiem gímenes aprūpē nodotajiem pacientiem tikai viens tika atsūtīts atpakal uz slimnīcu. Redzot, ka Daugavpils slimnīcas darbinieki sekmīgi lauku saimniecībās izmitina pacientus, ieinteresējās arī citi. Pirms pacientu

106 Buduls H. Latvijas galvas pilsētas Rīgas Sarkankalna slimnīcas vēsture 1862.-1937. - Rīga: Pilsētas valdes izdevums, 1938. - 184. lpp.

107 Pārpildītas vājprātīgo slimnīcas // Jaunākās Ziṇas, 1936. g. 5. jūn.; 124: 4. 1pp.

108 Veselības departamenta apkārtraksts Nr. V./2280 un Nr. V./2700 par slimnieku izdošanu ǵimenes kopšanā - 1936. gada 8.-9. jūlijs // Lībiete I. Latvijā pirmā psihiatriskā kolonija ārsta Arnolda Laksberga atmin̄ās / Acta medico-historica Rigensia. - Vol. IX (XXVIII). - 2010. - 366.-367. 1pp.

109 Pārpildītas vājprātīgo slimnīcas // Jaunākās Ziņas, 1936. g. 5. jūn.; 124: 4. 1pp.; Lībiete I. Latvijā pirmā psihiatriskā kolonija ārsta Arnolda Laksberga atmin̄ās / Acta medico-historica Rigensia - Vol. IX (XXVIII). - 2010. - 366. 1pp.; Buduls H. Latvijas galvas pilsētas Rīgas Sarkankalna slimnīcas vēsture 1862.-1937. Rīga: Pilsētas valdes izdevums, 1938. - 188. lpp.

110 Buduls H. Latvijas galvas pilsētas Rīgas Sarkankalna slimnīcas vēsture 1862.-1937. - Rīga: Pilsētas valdes izdevums, 1938. - 188. 1pp.

111 LVVA, 2917. f., 1. apr., 2. 1., 14. 1p.

112 LVVA, 4578. f., 1. apr., 2491. 1., 75. 1p. 
izdeva pie lauksaimnieka, slimnīca pieprasīja no attiecīgā pagasta valdes lauksaimnieka personības un materiālā stāvokḷa raksturojumu. ${ }^{113}$ Mājas aprūpē nodotā pacienta sadzīves apstākḷus regulāri uzraudzịja slimnīcas pilnvarota persona. ${ }^{114}$ Gadu pēc šīs prakses uzsākšanas, 1937. gada jūlijā, no Daugavpils slimnīcas izrakstīti un ǵimenes kopšanā atradās jau 75 pacienti, ${ }^{115}$ bet novembrī - 96 pacienti. ${ }^{116}$ Sekmīgā prakse gan nevarēja attīstīties plašumā, jo jau 1937. gada novembrī Veselības departaments Daugavpils slimnīcu brīdināja, ka izvietošana ǵimenēs ir jāierobežo, jo saimnieciskā gada līdzekḷu pietiek tikai 85 slimnieku izvietošanai. ${ }^{117}$ 1939. gadā valsts psihiatriskās slimnīcas mājas kopšanai bija izdevušas 222 slimniekus, no tiem lielāko daļu - 145 pacientus - Daugavpils psihiatriskā slimnīca. Jelgavas psihiatriskā slimnīca 1939. gadā mājas aprūpē bija izdevusi 40, Strenču psihiatriskā slimnīca - 26, bet Aleksandra Augstumu slimnīca - tikai 11 pacientus. ${ }^{118}$

Pacientu izrakstīšana mājas aprūpei varēja tikt īstenota divos veidos. Pacientu varēja nodot mājas aprūpē pie viṇa tuviniekiem vai pie svešiem cilvēkiem. Slimnieku izmitināšana pie tuviniekiem bija vienkāršāk īstenojama, taču par perspektīvāku tika uzskatīta pacientu izmitināšana "audžuǵimenēs" - visbiežāk lauku saimniecībās, kur pacienti savu iespēju robežās varēja strādāt kādu vienkāršu, bet derīgu darbu. Pastāvēja iecere, ka šāda pacientu izvietošana un nodarbināšana lauksaimnieku ǵimenēs ar laiku varētu novest pie psihiatriskās kolonijas izveides, kas, atsaucoties uz labo praksi Gēlas kolonijā Beḷgijā, varētu ievērojami samazināt pacientu uzturēšanas izmaksas. ${ }^{119}$ 1928. gadā H. Buduls, apkopojot ziņas no psihiatriskajām slimnīcām, secināja, ka kopumā ap 10\% mierīgo hroniski

113 LVVA, 4578. f., 1. apr., 2491. 1., 71., 75. 1p.

114 LVVA, 4578. f., 1. apr., 2492. 1., 43.-44. lp.; Lībiete I. Latvijā pirmā psihiatriskā kolonija ārsta Arnolda Laksberga atmin̄ās // Acta medico-historica Rigensia. Vol. IX (XXVIII). - 2010. - 366.-367. lpp.

115 LVVA, 4578. f., 1. apr., 2491. 1., 64.-68. 1p.

116 Turpat, 107.-112. 1p.

117 Turpat, 93. 1p.

118 Slimnieku kustība Valsts psichiatriskās slimnīcās // Tautas Labklājības Ministrijas Mēnešraksts, 1940; 3: 224. 1pp.

119 Neubergs K. Psīchiatriskās slimnīcas, to darbība, uzdevumi un viedokḷi: Rakstu sakopojums Ģintermuižas slimnīcas (dib. 1887. gada 3. jūnijā) 50 gadu darbības atcerei. - Jelgava: Tautas labklājības ministrijas Veselības departamenta Ģintermuižas slimnīca, 1938. - 19.-20. lpp. 
slimo pacientu varētu izvietot pavisam vienkāršā patversmē bez jebkādas medicīniskās uzraudzības. ${ }^{120}$

H. Buduls saskaņā ar citu valstu pieredzi sprieda, ka būtu lietderīgi šo sirdzēju izmitināšanai dibināt slimnīcu - koloniju, kurā slimniekus varētu ne tikai aprūpēt, bet arī nodarbināt. ${ }^{121}$ Tāpēc arī Latvijā 20. gs. 20. gadu beigās radās iecere izveidot šāda veida koloniju Ventspils apriņ̧̧̦̄i Popes muižā, kas uzņemtu ap 200 mierīgu hronisko psihiatrisko pacientu. ${ }^{122}$ Valdība šajā iniciatīvā vairāk redzēja iespēju ietaupīt, jo bija paredzams, ka šādas kolonijas noteikti izmaksātu mazāk nekā slimnieku uzturēšana psihiatriskajā slimnīcā. Savukārt psihiatri saskatīja arī būtisku ieguvumu pašiem slimniekiem.

Veselības departaments jau 1926. gada jūlijā bija griezies pie Ventspils apriņķ̧a zemes ierīcības komitejas ar lūgumu piešksirt Popes pili ar vairākām ēkām "vājprātīgo kolonijas ierīkošanai", ${ }^{23}$ kuras iekārtošanu bija paredzēts sākt jau nākamajā gadā. ${ }^{124}$ Šādus plānus psihiatriskās aprūpes uzlabošanai 1927. gada sākumā apliecināja arī Veselības departamenta direktors Augusts Pētersons. ${ }^{125}$ Popes muižas pils sākotnēji piederēja pagastam, bet 1927. gada maijā kopā ar blakus ēkām, parku un diviem hektāriem zemes tā tika piešķirta Tautas labklājības ministrijai, ar piebildi "piešķirts garā slimo kolonijas vai tuberkulozes slimnīcas ierīkošanai". ${ }^{26}$ Popes pils ēka bija labā stāvoklī - "būvēta pēc koridoru sistēmas" un "ar l̦oti labi uzglabātām holandiešu majolikas krāsnīm un visām labierīcībām”, plašu parku un auglı dārzu. ${ }^{127}$

${ }^{120}$ Buduls H. Par garīgi slimo apgādību Latvijā //Latvijas Ārstu Žurnāls, 1929; 7/8: 576. -579 . lpp.

121 Turpat, 578. 1pp.

122 Galvas pilsēta. Vājprātīgo slimnīcas paplašinās // Latvijas Kareivis, 1928. g. 9. okt.; 229: 2. lpp.; Vājprātīgo slimnīcu paplašināšana // Latvijas Kareivis, 1929. g. 15. jūn.; 132: 4. lpp.; Apriņķu valžu pārstāvju 1929. gada 11. oktobra apspriedē pieņemtie atzinumi // Iekšlietu Ministrijas Vēstnesis, 1929. g. 18. okt.; 342: 2. lpp.

123 Jauna vājprātīgo kolonija // Latvijas Sargs, 1926. g. 28. jūl.; 156: 1. lpp.

${ }^{124}$ Cīņā pret diloni, lepru un gara slimībām // Latvis, 1926. g. 16. jūl.; 1429: 1. lpp. 125 Pētersons A. Veselības stāvoklis Latvijā // Tautas Veselība, 1927; 1: 1. lpp.

126 Galīgi piešksirtās rūpniecības iestādes, aug̣̣u dārzi un t. t. // Zemes Ierīcības Vēstnesis, 1927. g. 22. jūl.; 247: 27. lpp

127 Pašvaldību darbība Ventspils apriņķ̄ī // Valdības Vēstnesis, 1930. g. 16. okt.; 235: 3. lpp. 


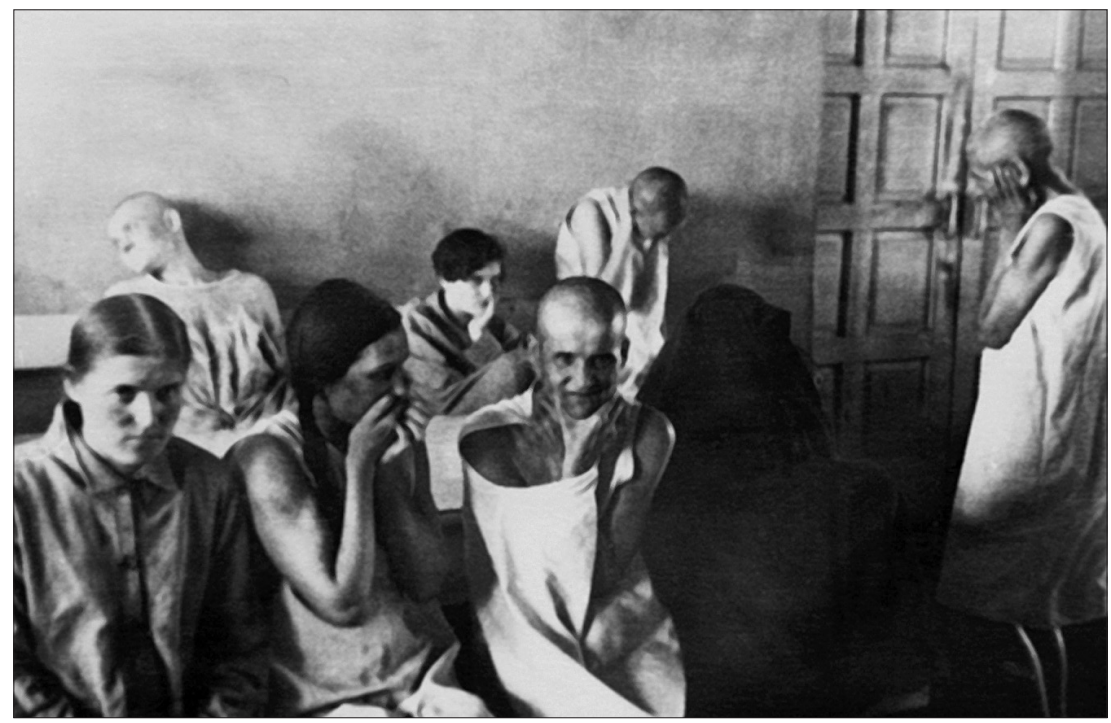

Daugavpils slimnīcas "nemierīgo" sieviešu dienas telpas, 20. gs. 30. gadi

Par spīti labajiem nodomiem kolonijas iekārtošana stipri aizkavējās. Jautājums tika atkal aktualizēts 1929. gada oktobra apriņķu valžu pārstāvju sēdē, kurā tie pieprasīja valdībai paplašināt psihiatriskās slimnīcas un "Popes muižā ierīkot vājprātīgiem koloniju". ${ }^{128}$

1929. gadā tika izstrādāts hroniski vājprātīgo slimnīcas-patversmes Popes muižā detalizēts budžeta projekts 1929./1930. budžeta gadam. ${ }^{129}$ Projektā redzams, ka kolonijā plānoja izmitināt 150 hroniskos slimniekus, paredzēja izveidot lauksaimniecības un lopkopības saimniecību, atslēdznieku, kurpnieku un drēbnieku darbnīcas, kurās nodarbināt kolonijas iemītniekus. Par darbu bija paredzēts slimniekus arī atalgot. Kopumā kolonijas izveidei un tās darbības nodrošināšanai 1930. gadā nepieciešamais finansējums tika aprēķināts 244599 latu, kas bija aptuveni puse no lielo psihiatrisko slimnīcu kopfinansējuma.

128 Apriņķu valžu pārstāvju 1929. gada 11. oktobra apspriedē pieņemtie atzinumi // Iekšlietu Ministrijas Vēstnesis, 1929. g. 18. okt.; 342: 2. lpp.

${ }^{129}$ LVVA, 4578. f., 4. apr., 404. 1. 


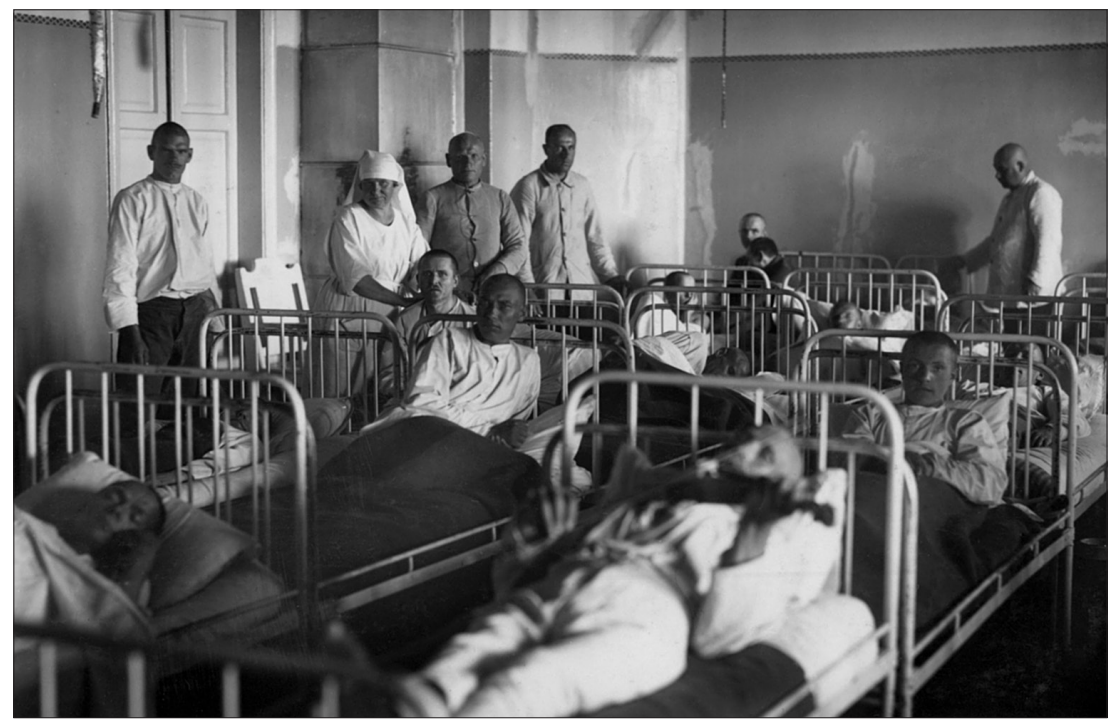

Daugavpils slimnīcas hronisko pacientu guḷamtelpas, 20. gs. 30 . gadi

Tomēr Popes kolonija, šķiet, tā arī netika izveidota. Zināms, ka 1930. gada vasarā Popē psihiatriskā kolonija vēl nedarbojās, jo Tautas labklājības ministrija minētā gada vasarā Popes pilī bija ierīkojusi bērnu vasaras koloniju. Turklāt jau tajā pašā gadā Ventspils apriņķa pašvaldība Tautas labklājības ministrijai ierosināja šo êku atdot atpakalı, lai Ventspils apriņķis kopā ar Ventspils pilsētu tur ierīkotu kopīgu slimo nespējnieku patversmi. ${ }^{130}$ Zināms, ka arī 1937. gada vasarā Popes muižas ēkas bija tukšas un ka valsts sev piederošo muižu bija nodomājusi atdot kādai no Kurzemes pilsētu pašvaldībām, lai tā tur ierīko tuberkulozes sanatoriju vai kādu citu veselības iestādi, ${ }^{131}$ tādējādi centieni izveidot psihiatrisko koloniju beidzās nesekmīgi. Pirmo psihiatrisko koloniju Latvijā izveidoja vēlāk, tikai Otrā pasaules kara laikā Rīgā, Ģimnastikas ielā, tā gan pastāvēja tikai pavisam neilgu laiku - no 1941. gada sākuma līdz tā paša gada jūnijam. ${ }^{132}$

130 Pašvaldības departamenta direktors par revizijam Ventspils apriṇksī // Iekšlietu Ministrijas Vēstnesis, 1930. g. 14. okt.; 434: 3. lpp.

131 Popes muižā iekārtos sanatoriju // Rīts, 1937. g. 14. aug.; 221: 9. lpp.

${ }^{132}$ Lībiete I. Latvijā pirmā psihiatriskā kolonija ārsta Arnolda Laksberga atmiṇās // Acta medico-historica Rigensia - Vol. IX (XXVIII). - 2010. - 364.-371. lpp. 
Noslēgumā jābilst, ka Latvijā starpkaru periodā, par spīti visām pūlēm situāciju psihiatriskajā aprūpē uzlabot, slimnīcu pārliekas noslogotības jautājums un gultas vietu trūkums akūti saslimušajiem saglabājās nemainīgi aktuāls. Attīstoties psihiatrijai kā akadēmiskai disciplīnai un ieviešot psihiatrijas klīniskajā praksē laikmeta modernākās ārstēšanas metodes malārijas drudža terapiju progresīvās paralīzes ārstēšanā (1923) ${ }^{133}$ un insulīna un kardiazola šoka terapijas šizofrēnijas ārstēšanā (1936)134 - garīgi slimajiem cilvēkiem (teorētiski) bija iespējams saņemt tā laika standartiem atbilstošu psihiatrisko aprūpi. Taču nesakārtotas sociālās aprūpes dēl psihiatriskās aprūpes pieejamība bieži bija apgrūtināta.

\section{Kopsavilkums}

Pēc Pirmā pasaules kara, Latvijas Republikas laikā, veidojoties industrializētas sabiedrības modelim, mainījās arī attieksme pret garīgajām slimībām un psihiatriju. Psihiatrisko pacientu aprūpe no iepriekš dominējošās mājas aprūpes pārgāja medicīnas un institucionalizētās psihiatrijas jurisdikcijāa. Tas radīja arvien pieaugošu pieprasījumu pēc gultas vietām psihiatriskos stacionāros un veicināja psihiatrisko stacionāru nemitīgu paplašināšanu. Taču valsts, pašvaldību, psihiatru un sabiedrības iesaiste psihiatriskās aprūpes problēmu risināšanā nespēja tās atrisināt - visu laiku nemain̄̄gi saglabājās apgrūtināta psihiatriskās aprūpes pieejamība, bet pašās slimnīcās - to reālajām iespējām pārāk liels pacientu skaits. Tas galvenokārt bija saistīts ar vāji organizētu psihiatrisko pacientu sociālo aprūpi.

${ }^{133}$ Lībiete I. Sifiliss, dementia paralytica un malārijas drudža terapija Latvijas psihiatru praksē 20. gadsimta 20. gados // Rīgas Stradiņa universitātes 2010. gada zinātniskā konference. Tēzes. - Rīga, 2010. - 443. lpp.

${ }^{134}$ Libiete I. Fighting schizophrenia: Beginnings of somatic treatments in psychiatry in Riga Sarkankalns hospital in the 1930s // Baltic Journal of European Studies, 2011; 1 (9): 257-268. 


\title{
Psychiatric Health Care in Latvia in the 1920s and 1930s
}

\begin{abstract}
After the World War I Latvia proclaimed its independence. Following the industrialization and urbanization, the attitude towards mental illness and psychiatry began to change. Previously dominant home and community care for mental illness was replaced by medical care in psychiatric institutions. The request for institutionalized psychiatric care started to grow rapidly. It was followed by ongoing expansion of inpatient treatment facilities. Despite the efforts of state, local governments, psychiatrists and the public to deal with problems in this area, access to psychiatric care remained difficult throughout the entire period, with the hospitals themselves always having too many patients. This was mostly down to poorly organized social care for psychiatric patients.
\end{abstract}

Ieva Lībiete, $D r$. med., lektore

Rīgas Stradiņa universitāte

ieva.libiete@rsu.lv 